\title{
Polydora and Related Genera Associated with Hermit Crabs from the Indo-West Pacific (Polychaeta: Spionidae), with Descriptions of Two New Species and a Second Polydorid Egg Predator of Hermit Crabs ${ }^{1}$
}

\author{
Fason D. Williams ${ }^{2}$
}

\begin{abstract}
Polydora and related genera associated with hermit crabs from shallow subtidal coral reef areas of the Indo-West Pacific are described. Over 2000 hermit crabs were collected from localities in the Philippines and Indonesia between July 1997 and April 1999. In total, 10 species of polychaetes among five genera (Boccardia, Carazziella, Dipolydora, Polydora, and Tripolydora) were identified and described. Adult morphology of these species was investigated with light microscopy and scanning electron microscopy. The study includes the description of two new Polydora species, including the second known polydorid egg predator of hermit crabs. Six of the species burrow into calcareous substrata, living in burrows within live or dead gastropod shells or coralline algae attached to shells. Two species were found in mud tubes within crevices of gastropod shells inhabited by hermit crabs. The zoogeography and biodiversity of polydorids from the West Pacific are discussed. The diversity of polydorids from the Philippines is comparable with that of other central Pacific and Indo-West Pacific islands, but it is lower than that in areas of the North and Southwest Pacific; lower diversity probably reflects disparity in sampling efforts between these regions. A key to the Philippine polydorids is provided.
\end{abstract}

Polychaetes are common associates of hermit crabs, either living on, within, or burrowing into occupied gastropod shells (e.g., Jensen and Bender 1973, Stachowitsch 1980, Hoberg et al. 1982, Karlson and Shenk 1983, Walker 1995). In particular, Polydora and related genera (termed polydorids, nine genera of the family Spionidae that contain a modified fifth segment) are known to burrow into calcareous substrata including gastropod shells occupied by hermit crabs (Blake and Evans 1973, Read 1975, Radashevsky 1993,

${ }^{1}$ This work was supported by the Lerner-Gray Fund for Marine Research (American Museum of Natural History), a Libbie Hyman Memorial Scholarship (Society for Integrative and Comparative Biology), and a Graduate Fellowship from the University of Rhode Island. Manuscript accepted 3 February 2001.

${ }^{2}$ Department of Biological Sciences, 100 Flagg Road, University of Rhode Island, Kingston, Rhode Island 02881-0816. Current address: Department of Biology, Hofstra University, Hempstead, New York 11549-1140.

Pacific Science, vol. 55, no. 4:429-465

(C) 2001 by University of Hawai'i Press

All rights reserved
Blake 1996, Martin and Britayev 1998, Williams 2000). The burrowing behavior of these species has been investigated in substantial detail because of their effects on commercially important mollusk species (see Radashevsky and Williams 1998). Polydorids have been considered to be facultative or obligate commensals of hermit crabs, but recent research indicates that the worms can have negative effects on their hosts (Buckley and Ebersole 1994, Williams 2000). The purpose of this investigation was to examine the systematics and ecology of polydorids associated with hermit crabs from coral reef areas of the Indo-West Pacific.

The Spionidae is one of the most conspicuous polychaete families of Indo-West Pacific islands, in many areas second only to the family Syllidae in number of recorded genera (Knox 1957, Bailey-Brock 1995, Paxton and Chou 2000). Polydorids are common inhabitants of coral reef areas, and some species are bioeroders found to burrow in live and dead corals and mollusk shells (Hartman 1954, Bailey-Brock 1995). In spite of the amount of work completed in the North and 
Southwest Pacific (see Blake and Kudenov 1978, Radashevsky 1993, Sato-Okoshi 1999, Radashevsky and Hsieh 2000a,b), polydorids from central Indo-West Pacific areas such as the Philippines remain largely unknown. Before this investigation only two polydorid species had been identified from the Philippines, although a number of faunistic surveys of the polychaetes from the Philippines and surrounding areas have been completed (Pillai 1965, Williams 2000). Part of the success of polydorids is due to the possession of long prehensile palps allowing the worms to suspension and deposit feed or a combination of both (Williams and McDermott 1997). Other taxonomically important features of these worms include major spines of the fifth segment, branchial distribution, neuropodial hooded hook morphology, and pygidium morphology.

This paper represents part of a series of studies on the systematics, ecology, and feeding biology of polydorids associated with hermit crabs from the Indo-West Pacific. The first paper provided the description of Polydora robi, an obligate commensal of hermit crabs from the Philippines and Indonesia (Williams 2000). Polydora robi was documented to ingest the embryos of host hermit crabs, and the reproduction and larval development of the species have been investigated (Williams 2001). The study reported here provides records of 10 species of polydorids from the Philippines and Indonesia, nine of which are previously unrecorded from the Philippines and two are new to science. Morphology of representative species was investigated with scanning electron microscopy (SEM). Data on the ecology of these species and feeding biology of the second known egg predator of hermit crabs are provided.

\section{MATERIALS AND METHODS}

Hermit crabs inhabiting gastropod shells were collected intertidally and shallow subtidally $\left(<5 \mathrm{~m}\right.$ ) in Bataan (Mabayo, $14^{\circ} 44^{\prime} \mathrm{N}$, $120^{\circ} 16^{\prime} \mathrm{E}$; Morong, $\left.14^{\circ} 41^{\prime} \mathrm{N}, 120^{\circ} 16^{\prime} \mathrm{E}\right)$, Batangas (Anilao, $13^{\circ} 46^{\prime} \mathrm{N}, 120^{\circ} 56^{\prime} \mathrm{E}$; Sombrero Island, $13^{\circ} 42^{\prime} \mathrm{N}, 120^{\circ} 50^{\prime} \mathrm{E}$; Sepoc Point, $13^{\circ} 41^{\prime} \mathrm{N}, 120^{\circ} 50^{\prime} \mathrm{E}$ ), Oriental Mindoro (Puerto Galera: Coco Beach, $13^{\circ}$ $30^{\prime} \mathrm{N}, 120^{\circ} 56^{\prime} \mathrm{E}$; Puerto Galera: Big and Small Lalaguna Beaches, $13^{\circ} 30^{\prime} \mathrm{N}, 120^{\circ} 57^{\prime}$ E; Puerto Galera: Bayanan and Haligi Beaches, $13^{\circ} 29^{\prime} \mathrm{N}, 120^{\circ} 53^{\prime} \mathrm{E}$ ), Aklan (Boracay: Diniwid Beach, $11^{\circ} 60^{\prime} \mathrm{N}, 121^{\circ} 54^{\prime} \mathrm{E}$; Boracay: White Beach, $11^{\circ} 59^{\prime} \mathrm{N}, 121^{\circ} 55^{\prime} \mathrm{E}$; Boracay: Rocky Beach, $11^{\circ} 57^{\prime} \mathrm{N}, 121^{\circ} 56^{\prime}$ E), Palawan (El Nido: Magbautoc Island, $10^{\circ}$ $59^{\prime} \mathrm{N}, 119^{\circ} 36^{\prime} \mathrm{E}$; El Nido: Imbaladan Island, $10^{\circ} 58^{\prime} \mathrm{N}, 119^{\circ} 34^{\prime} \mathrm{E}$; El Nido: Apulit Island, $10^{\circ} 58^{\prime} \mathrm{N}, 119^{\circ} 37^{\prime} \mathrm{E}$ ), and Cebu (Mactan Island, $10^{\circ} 18^{\prime} \mathrm{N}, 123^{\circ} 58^{\prime} \mathrm{E}$; Olango Island, $\left.10^{\circ} 16^{\prime} \mathrm{N}, 124^{\circ} 03^{\prime} \mathrm{E}\right)$ Provinces of the Philippines (Figure 1) and in Bali (Sanur, $8^{\circ} 41^{\prime} \mathrm{S}$, $115^{\circ} 15^{\prime} \mathrm{E}$ ), Indonesia, from June to August 1997 and January to April 1999. All Philippine specimens were collected by the author.

Worms were removed from burrows after cracking the gastropod shells with a mortar and pestle constructed of galvanized steel pipe (60 $\mathrm{mm}$ in diameter). Specimens were relaxed in 3\% magnesium chloride in seawater, fixed in $4 \%$ formalin-seawater solution (1 part 39\% formalin and 9 parts seawater), rinsed in tap water, and stored in $70 \%$ ethyl alcohol. Sketches of live and preserved specimens were completed using a compound microscope with a drawing tube attachment. These sketches were scanned into a Macintosh computer and images were prepared using the programs Adobe Photoshop and Adobe Illustrator.

Adult morphology was examined with SEM. Specimens stored in $70 \%$ ethanol were dehydrated in an ascending ethanol series followed by four changes of $100 \%$ ethanol. Material was dehydrated with Peldri II by placing the specimens into a $1: 1$ mixture of $100 \%$ ethanol and Peldri II for $1 \mathrm{hr}$ at $34^{\circ} \mathrm{C}$. The specimens were transferred to $100 \%$ Peldri II for $3 \mathrm{hr}$ and then placed in a cool water bath and allowed to sublime overnight. Dried specimens were mounted on a copper stub, coated with gold-palladium mixture, and viewed in a SEM (JEOL 1200EX).

Specimens were borrowed from the $\mathrm{Na}$ tional Museum of Natural History (USNM) and the National Museum of Victoria (NMV). Type and representative materials from this study are deposited in the American Museum of Natural History (AMNH) and USNM. 


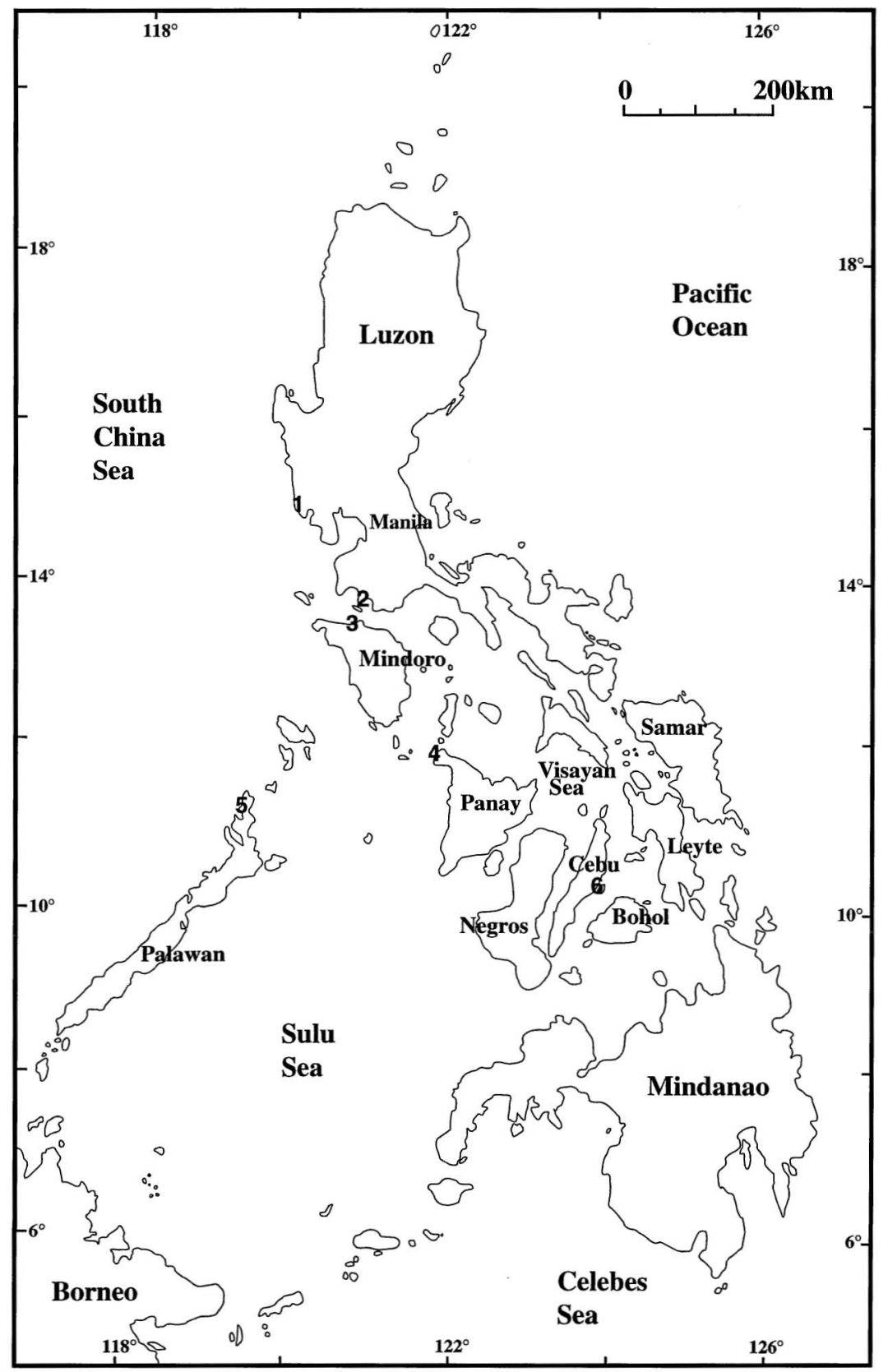

Figure 1. Map of the Philippines with six provinces indicated in the text: 1, Bataan; 2, Batangas; 3, Oriental Mindoro; 4, Aklan; 5, Palawan; 6, Cebu. 
KEY TO THE POLYDORID SPECIES FROM THE PHILIPPINES

(Figure numbers in parentheses)

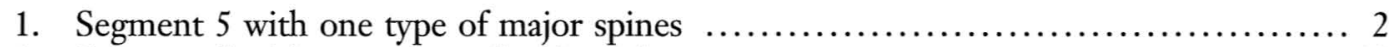

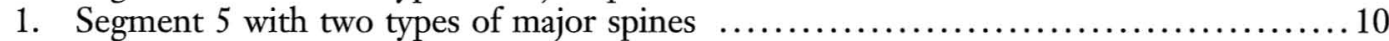

2. Branchiae begin on segment 2; tridentate hooded hooks (157); segment 4 with modified notosetae $(15 G)$; segment 5 weakly modified ............... Tripolydora spinosa

2. Branchiae begin posterior to segment 5 ; bidentate hooded hooks; segment 5 highly

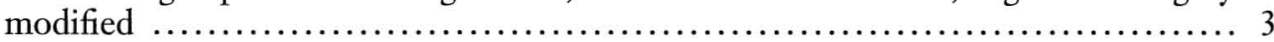

3. Notosetae present on segment $1(5 A ; 7 A ; 9 A)$; hooded hooks without constriction on shaft $(7 E ; 9 C)$

3. Notosetae absent on segment $1(11 A ; 12 A ; 14 A)$; hooded hooks with constriction on shaft $(11 C ; 12 E)$

4. Posterior notopodial spines present; spines thick, acicular $(5 B, C ; 6 C, G, E)$

4. Posterior notopodial spines absent

Dipolydora armata

5. Major spines of segment 5 with small protuberance $(8 C, D)$; pygidium with large ventral lobe and 2 smaller dorsal lobes $(7 B, D ; 8 B) \ldots \ldots \ldots \ldots \ldots \ldots \ldots$ Dipolydora socialis

5. Major spines of segment 5 with two lateral teeth $(9 B ; 10 B, D)$; small cuff-shaped pygi-

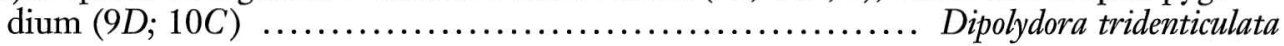

6. Bundles of needlelike notosetae protruding through cuticle in posterior segments; pygidium with anal cirri $\ldots \ldots \ldots \ldots \ldots \ldots \ldots \ldots \ldots \ldots \ldots \ldots \ldots \ldots \ldots$ Polydora $r o b i$

6. Bundles of posterior notosetae absent; cup-shaped pygidium $\ldots \ldots \ldots \ldots \ldots \ldots \ldots \ldots .7$

7. Major spines of segment 5 simple, falcate $(14 D, F) \ldots \ldots \ldots \ldots \ldots$. Polydora mabinii

7. Major spines of segment 5 with lateral tooth or flange $\ldots \ldots \ldots \ldots \ldots \ldots \ldots \ldots \ldots$

8. Occipital tentacle present $\ldots \ldots \ldots \ldots \ldots \ldots \ldots \ldots \ldots \ldots \ldots \ldots \ldots$ Polydora cavitensis*

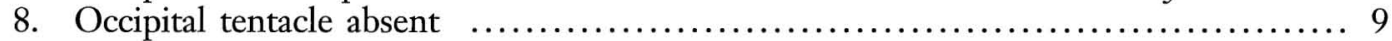

9. Palps crossed by bars of black pigmentation $(11 A)$; caruncle to end of segment

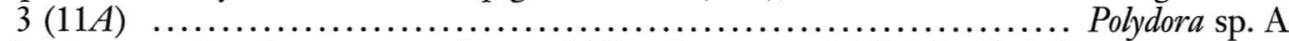

9. Palp pigmentation absent; caruncle to middle of segment $2(12 A, D ; 13 A, C)$

Polydora umangivora

10. Branchiae begin on segment $2(2 A ; 3 A, B)$

Boccardia berkeleyorum

10. Branchiae begin on segment $7(4 A)$ Carazziella reishi

*Species not encountered during this study.

\section{SYSTEMATIC ACCOUNT}

Family Spionidae Grube, 1850

Genus Boccardia Carazzi, 1893

Perialla Kinberg, 1866:353. Type species: Perialla claparedei Kinberg, 1866, by monotypy. (See Remarks section.)

Boccardia Carazzi, 1893:15. Type species: Polydora polybranchia Haswell, 1885, by monotypy.
Paraboccardia Rainer, 1973:550. Type species: Paraboccardia syrtis Rainer, 1973, by original designation.

Neoboccardia Buzhinskaja, 1985:129. Type species: Polydora perata Khlebovitsch, 1959, by monotypy.

REMARKs: The genus Boccardia has been reviewed by Blake and Woodwick (1971) and emended by Blake and Kudenov (1978). To 
date 20 species of Boccardia have been described (see Blake and Kudenov 1981, Hutchings and Turvey 1984, Blake 1986, Guérin 1990). As indicated by Blake (1983), the genus name Perialla Kinberg, 1866, has priority over Boccardia Carazzi, 1893. However, since the description of Perialla claparedei by Kinberg (1866) the genus name has not been utilized by any other author, although Kinberg's description of this species was reprinted (Kinberg 1910). Article 23.9.1 of the International Code of Zoological Nomenclature (ICZN 1999) indicates that prevailing usage must be maintained when a senior synonym has not been used as a valid name after 1899 (23.9.1.1) and when the junior synonym has been used in at least 25 publications by at least 10 authors in the last $50 \mathrm{yr}$ (23.9.1.2). The second condition of article 23.9.1 is fulfilled, but the first condition is not strictly met, although in a practical sense it is because no author other than Kinberg has utilized the name Perialla after 1899. For these reasons and to serve taxonomic stability, I conclude that Perialla should be considered a nomen oblitum and that Boccardia be considered a nomen protectum to preserve the current usage of Boccardia.

DIAGNosis: Prostomium with anterior incision or rounded; caruncle extending posteriorly, surrounded by cilia of nuchal organ. Segment 1 with or without notosetae. Segment 5 modified with two types of heavy spines arranged in a double row: dorsal row simple, falcate; ventral row with expanded tip and accessory structures bearing bristles. Posterior notosetae in form of capillaries or specialized spines. Bidentate hooded hooks begin on segments 7-11; main fang at approximately right angle to shaft, with wide angle between main fang and apical tooth, no constriction on shaft. Branchiae on segments 2-4, 6, and subsequent segments. Pygidium lobed, cuffshaped or disk-shaped with or without separate lobes.

\section{Boccardia berkeleyorum Blake \& Woodwick,} 1971

Figures 2, 3
Boccardia berkeleyorum Blake \& Woodwick, 1971:34-36, fig. 2a-k; Sato-Okoshi and Okoshi, 1997:486.

material examined: Philippines: Batangas: 5 spec. (USNM 187516: 4 spec.; USNM 187517: 1 spec., on 2 SEM stubs), from Drupa rubusidaeus (Röding) inhabited by unidentified hermit crabs, Sombrero Island, 13 July 1997; 4 spec. (АмNH 4246) from dead bivalve shells and Drupella cornus (Röding) inhabited by Dardanus lagopodes, Sombrero Island, 30 January 1999; Oriental Mindoro: 1 spec. (USNM 187518), from Drupa sp. inhabited by Calcinus gaimardii (MilneEdwards), Puerto Galera: Big Lalaguna Beach, 31 July 1997. United States: California: Cayucos: 2 paratypes (USNM 48761), from Tegula brunnea (Philippi) occupied by Pagurus granosimanus (Stimpson), 28 August 1961, leg. K. H. Woodwick.

DESCRIPTION: $U p$ to $12.1 \mathrm{~mm}$ long, $0.7 \mathrm{~mm}$ wide at segment $7 ; 80$ segments. Prostomium with slight indentation; caruncle extending to end of segment 3; occipital tentacle and eyes absent (Figures $2 A, 3 A$ ). Palps short, with bars of white pigmentation. Black pigmentation on sides of prostomium and peristomium, and dusky black pigmentation on dorsal side of all segments, most prominent on posterior segments (Figure 2A). Slight dusky black pigmentation on ventral side of prostomium and anterior segments; pigment nearly absent after preservation; in alcohol body opaque white to light tan.

Segment 1 with neurosetae, weakly developed notopodial lobes, lobes more prominent in life, notosetae absent (Figures $2 A, 3 A, B$ ). Winged capillary notosetae of segments 2-4, 6 , and subsequent segments in two rows, notosetae of posterior row longer (Figure $3 A, B$ ); middle segments with two acicular spines accompanied by two capillary setae; in some specimens reduced to one acicular spine in posterior segments and two capillary setae (Figures $2 B, 3 C$ ). Winged capillary neurosetae of segments 2-4, 6, and subsequent segments in two rows (Figure $3 B$ ); four bidentate hooded hooks begin on segment 7 , up to five in series at segment 15 , accom- 


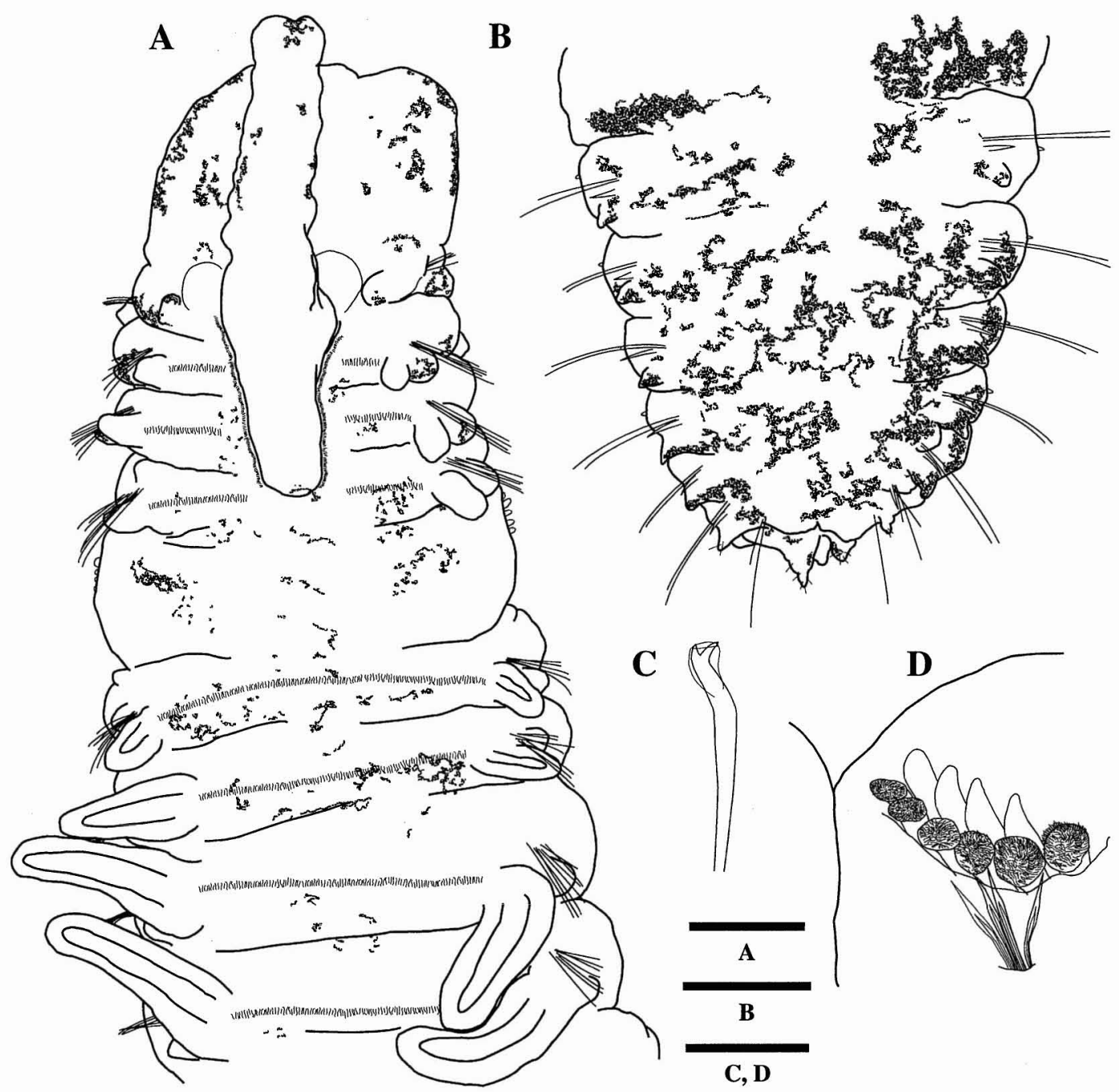

Figure 2. Boccardia berkeleyorum Blake \& Woodwick (AmNH 4246). $A$, Anterior end, dorsal view; $B$, posterior end, dorsal view; $C$, bidentate hooded hook from anterior segment; $D$, falcate and bristle-topped spines and companion setae of fifth segment, lateral view. Scale: $A, B, 150 \mu \mathrm{m} ; C, D, 50 \mu \mathrm{m}$.

panied by one or two winged capillaries; hooks with wide angle between main fang and apical tooth, approximately right angle between main fang and shaft, without constriction on shaft, with fine bristles on hood (Figures 2C, 3D).

Segment 5 with ventral fascicle of four winged capillary neurosetae; notosetae absent. Major spines of two types in curved, double row; four to six simple falcate spines dorsal to five to seven bristle-topped spines (Figures 2D, 3B,E).

Branchiae on segments 2-4, 6, and subsequent segments (Figures $2 A, 3 A, B$ ); attaining full size at segment 8 , absent from posterior one-fourth of body; nototrochs from segment 2 .

Pygidium with three to four irregularly shaped lobes surrounding anus, lobes with nonmotile cilia (Figures $2 B, 3 C$ ). 

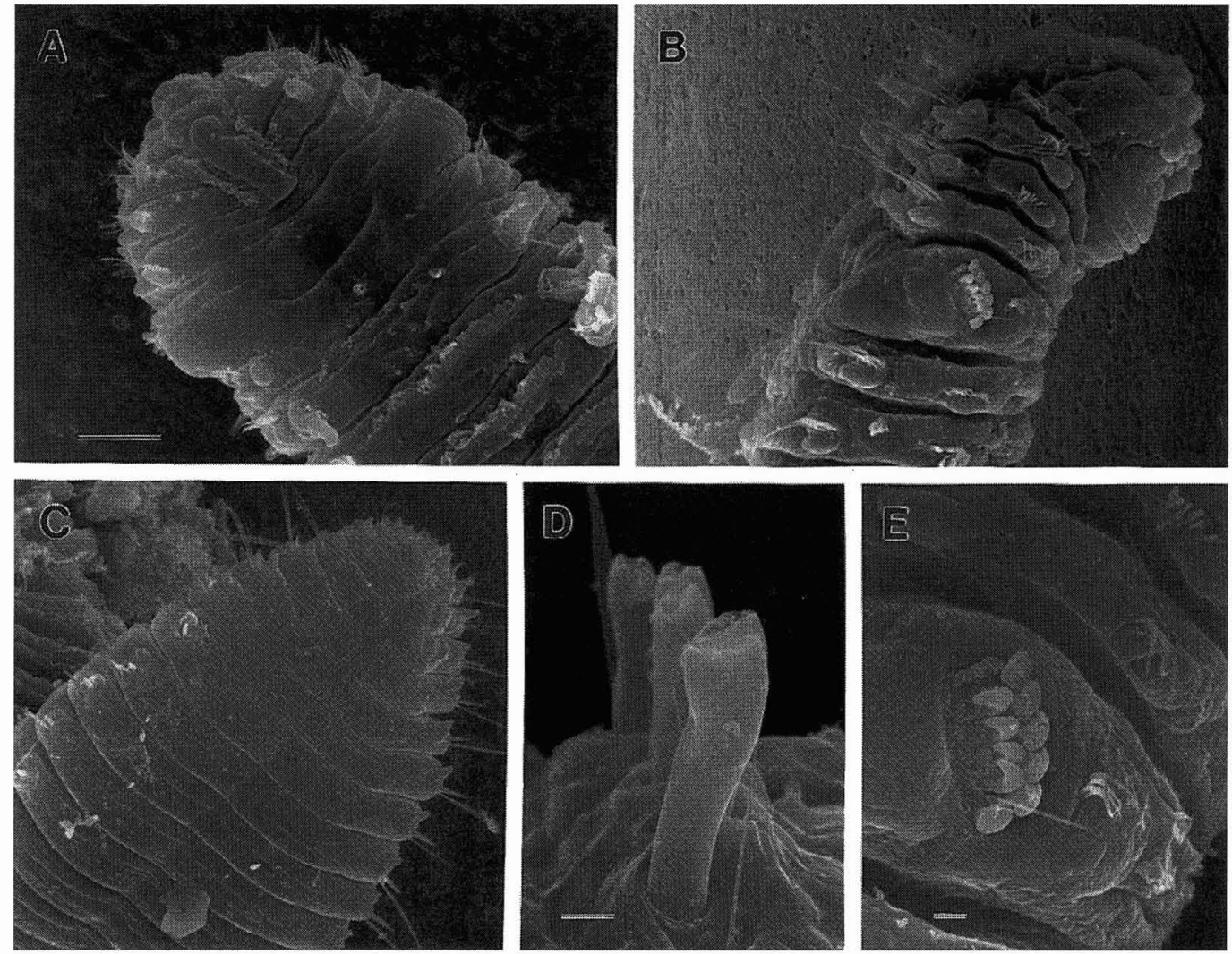

Figure 3. Boccardia berkeleyorum Blake \& Woodwick (USNM 187517), SEM micrographs. $A$, Anterior end, dorsal view; $B$, anterior end, lateral view of right side; $C$, posterior end, dorsal view; $D$, bidentate hooded hooks from anterior segment; $E$, falcate and bristle-topped spines and companion setae of fifth segment, lateral view. Scale: $A-C, 100 \mu \mathrm{m}$ $(B, C$, see scale bar in $A) ; D, E, 10 \mu \mathrm{m}$.

Remarks: The Philippine specimens agree well with the original description by Blake and Woodwick (1971). However, these specimens possess weakly developed notopodial lobes on segment 1 not observed in the holotype, possibly due to contraction after preservation. Black pigmentation on the new specimens is observed in life, but is absent from specimens preserved in alcohol for more than 6 months; white bars of pigment on the palps are also absent after preservation, but have been observed in Boccardia berkeleyorum specimens from Vancouver Island (SatoOkoshi and Okoshi 1997) and Boccardia cbilensis Blake \& Woodwick from New Zealand (Read 1975).
ECOLOGY: Boccardia berkeleyorum has been found in U-shaped burrows within gastropod shells occupied by Calcinus gaimardii, Dardanus lagopodes, and an unidentified hermit crab, in addition to dead bivalve shells. In California $B$. berkeleyorum is found within Tegula brunnea Philippi occupied by Pagurus granosimanus (Stimpson) (Blake and Woodwick 1971). Boccardia berkeleyorum is one of eight members of the genus known to bore into calcareous substrata: $B$. acus Rainer, $B$. anopthalma (Rioja), B. chilensis, $B$. galapagense Blake, B. lamellata Rainer, B. otakouica Rainer, and B. tricuspa (Hartman).

Distribution: United States: California (Blake and Woodwick 1971); Canada: Van- 
couver Island (Sato-Okoshi and Okoshi 1997); Philippines: Batangas, Mindoro (first record: this paper).

Genus Carazziella Blake \& Kudenov, 1978

Carazziella Blake \& Kudenov, 1978:240. Type species: Polydora citrona Hartman, 1941, by original designation.

DIAGNOSIS: Prostomium with anterior incision or rounded; caruncle short, sometimes divided with second ridge. Segment 1 with or without notosetae. Segment 5 modified with two types of heavy spines arranged in a double row: dorsal row falcate with or without bristles; ventral row with expanded tip and accessory structures bearing bristles. Bidentate hooded hooks begin on segments 7-14; main fang at approximately right angle to shaft, wide angle between main fang and apical tooth, no constriction on shaft. Branchiae begin on segments 7-10. Pygidium with two to four lobes or digitiform cirri.

Carazziella reishi (Woodwick, 1964)

Figure 4

Pseudopolydora reishi Woodwick, 1964:152154, fig. 3(1-3); Kohn and Lloyd, 1973a: 381; non Reish (1968:84).

Carazziella reishi (Woodwick): Blake, 1979a: 477-479, fig. 7; Sato-Okoshi, 1999:838, appendix 1, appendix 2 .

material examined: Philippines: Oriental Mindoro: $3 \mathrm{spec}$ (USNM 187520: $2 \mathrm{spec}$.; USNM 187519: 1 spec., on SEM stub), from Conus sp. inhabited by Ciliopagurus strigatus (Herbst), Puerto Galera: Big Lalaguna Beach, 31 July 1997. Marshall Islands: Eniwetok Atoll: holotype (USNM 32611), from sand among coral rock, Engebi, 7 September 1956, leg. D. J. Reish.

DESCRIPTION: Largest Philippine specimen $2.4 \mathrm{~mm}$ long, $0.3 \mathrm{~mm}$ wide at segment 7; 47 segments. Prostomium rounded; triangular caruncle extending to middle of segment 2 ; occipital tentacle absent; four eyes present (Figure 4A). Palps extending back to segment 18. In alcohol slight black pigmentation on prostomium (Figure $4 A$ ), body opaque white to light tan.
Segment 1 with noto- and neurosetae. Unilimbate capillary notosetae of segments $2-4,6$, and subsequent segments in two rows; reduced to three to four simple capillary notosetae in posterior segments; no specialized posterior spines. Unilimbate capillary neurosetae of segments 2-4, 6, and subsequent segments in two rows; two bidentate hooded hooks begin on segment 8 , up to three in series at segment 15 , accompanied by one capillary seta; hooks with wide angle between main fang and apical tooth, approximately right angle between main fang and shaft, no constriction on shaft, hood serrated (apparent via SEM only) (Figure 4H).

Segment 5 with posterioventral fascicle of four winged neurosetae. Notosetae absent in largest specimen; anteriodorsal fascicle of two capillary notosetae present in smaller specimen. Major spines of segment 5 of two types, ventral row of four bristle-topped spines with a cone lacking bristles, cone oriented apically (Figure $4 D$ ) or projecting laterally (Figure $4 E-G)$, and a dorsal row of three simple falcate spines (Figure $4 B, C, G$ ).

Branchiae begin on segment 7 , attaining full size at segment 8 , broad and overlapping at midline, continuing for four to nine segments.

Pygidium with four glandular lobes (Figure $4 I, 7)$, dorsal and ventral notches prominent, lateral divisions obscured (Figure 47).

Gizzardlike structure in the digestive tract absent.

REMARKs: One specimen differed from the holotype in presence of four eyes, rounded prostomium, and absence of notosetae on segment 5 . However, these characters are variable in other species of the genus (e.g., Carazziella carrascoi Blake) and therefore are insufficient for the erection of a new species.

ECOLOGY: The specimens were found in detrital burrows beneath encrusting coralline algae. The burrows of the worms extended through the algae, but not into the gastropod shells (Conus sp.) inhabited by Ciliopagurus strigatus. In the Marshall Islands and Indonesia, Carazziella reishi has been found in coral rocks (Woodwick 1964, Blake 1979a) and is the only member of the genus known to burrow into calcareous substrata. 


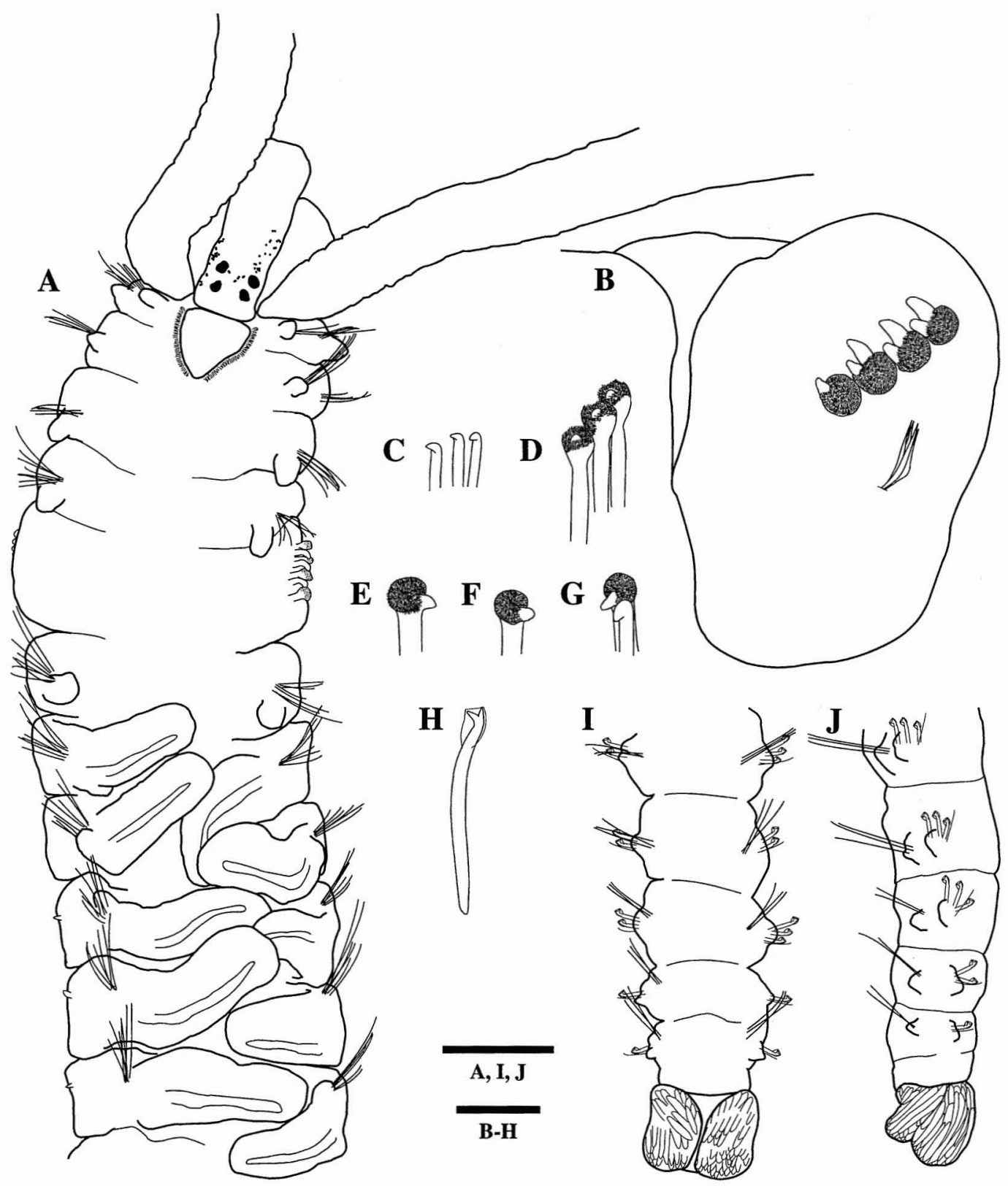

FIGURe 4. Carazziella reishi (Woodwick) (UsNm 187520). $A$, Anterior end, dorsal view; $B$, simple and bristle-topped spines and companion setae of fifth segment, lateral view; $C$, falcate spines of fifth segment. $D-F$, bristle-topped spines of fifth segment; $G$, falcate and bristle-topped spines of fifth segment; $H$, bidentate hooded hook from anterior segment; $I$, posterior end, dorsal view; $\mathcal{F}$, posterior end, lateral view. Scale: $A, I, \mathcal{F}, 100 \mu \mathrm{m} ; B-H, 30 \mu \mathrm{m}$. 
Distribution: Johnston Atoll (Ward 1981); Marshall Islands: Eniwetok Atoll (Woodwick 1964); Japan: Chikura, Shingu (Sato-Okoshi 1999); Philippines: Mindoro (first record: this paper); Indonesia: Bali, Pula Boonda (Blake 1979a).

Genus Dipolydora Verrill, 1879, sensu Blake, 1996

Dipolydora Verrill, 1879:174. Type species: Polydora concharum Verrill, 1879, designated by Verrill (1881).

DIAGNosis: Prostomium with anterior incision or rounded; caruncle extending pos- teriorly, surrounded by cilia of nuchal organ. Segment 1 with notosetae. Segment 5 modified with one type of major spines in a single curved row, with or without companion setae. Posterior notopodial spines present or absent. Bidentate hooded hooks begin on segments 7-17; obtuse angle between main fang and shaft, narrow angle between main fang and apical tooth; no constriction on shaft. Branchiae begin posterior to segment 5. Pygidium variable; cufflike, cup-shaped, or lobed. With or without gizzardlike structure in anterior part of digestive tract.

Dipolydora armata (Langerhans, 1880) Figures 5, 6

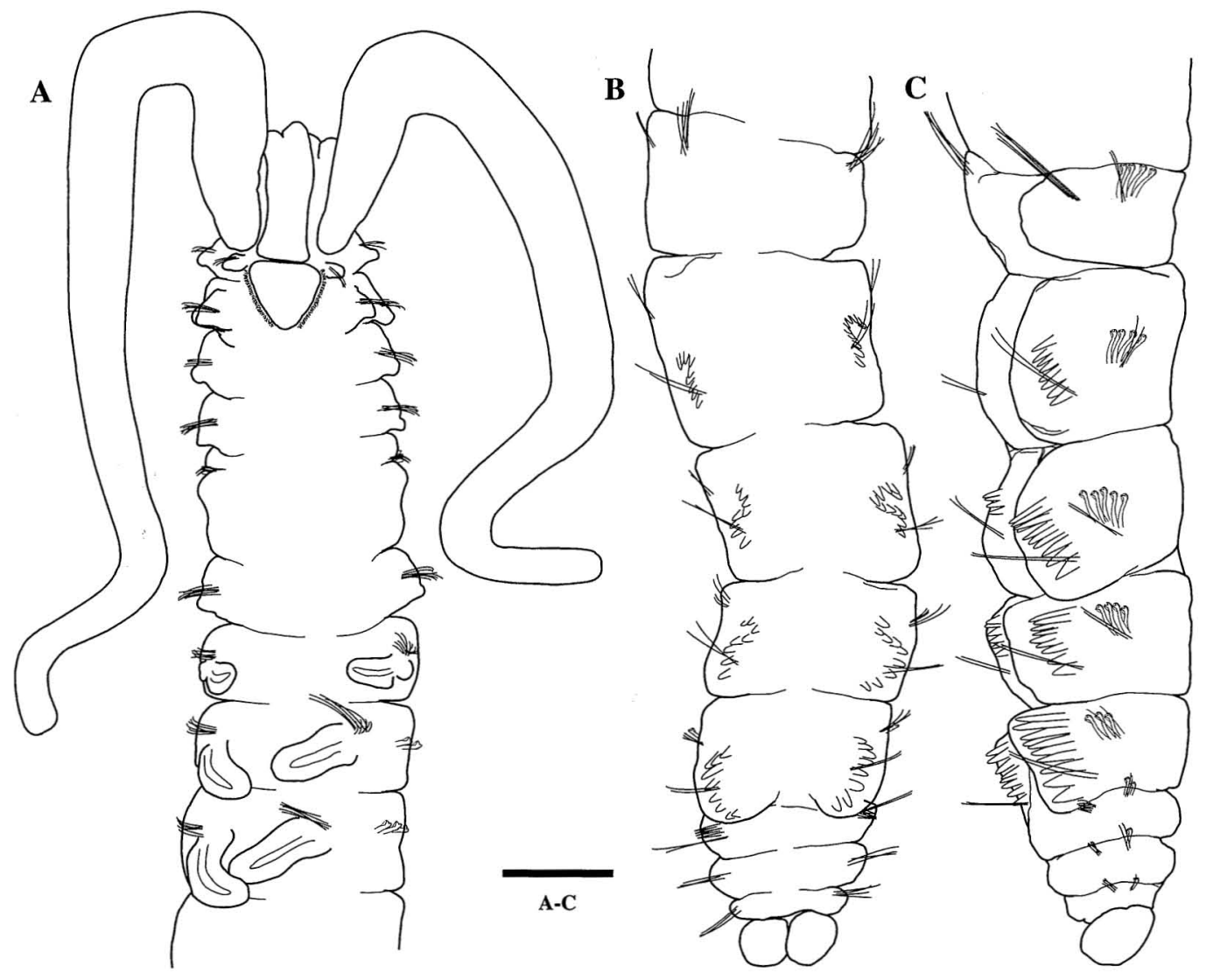

Figure 5. Dipolydora armata (Langerhans) (usnm 187530). $A$, Anterior end, dorsal view; $B$, posterior end, dorsal view; $C$, posterior end, lateral view. Scale: $A-C, 100 \mu \mathrm{m}$. 

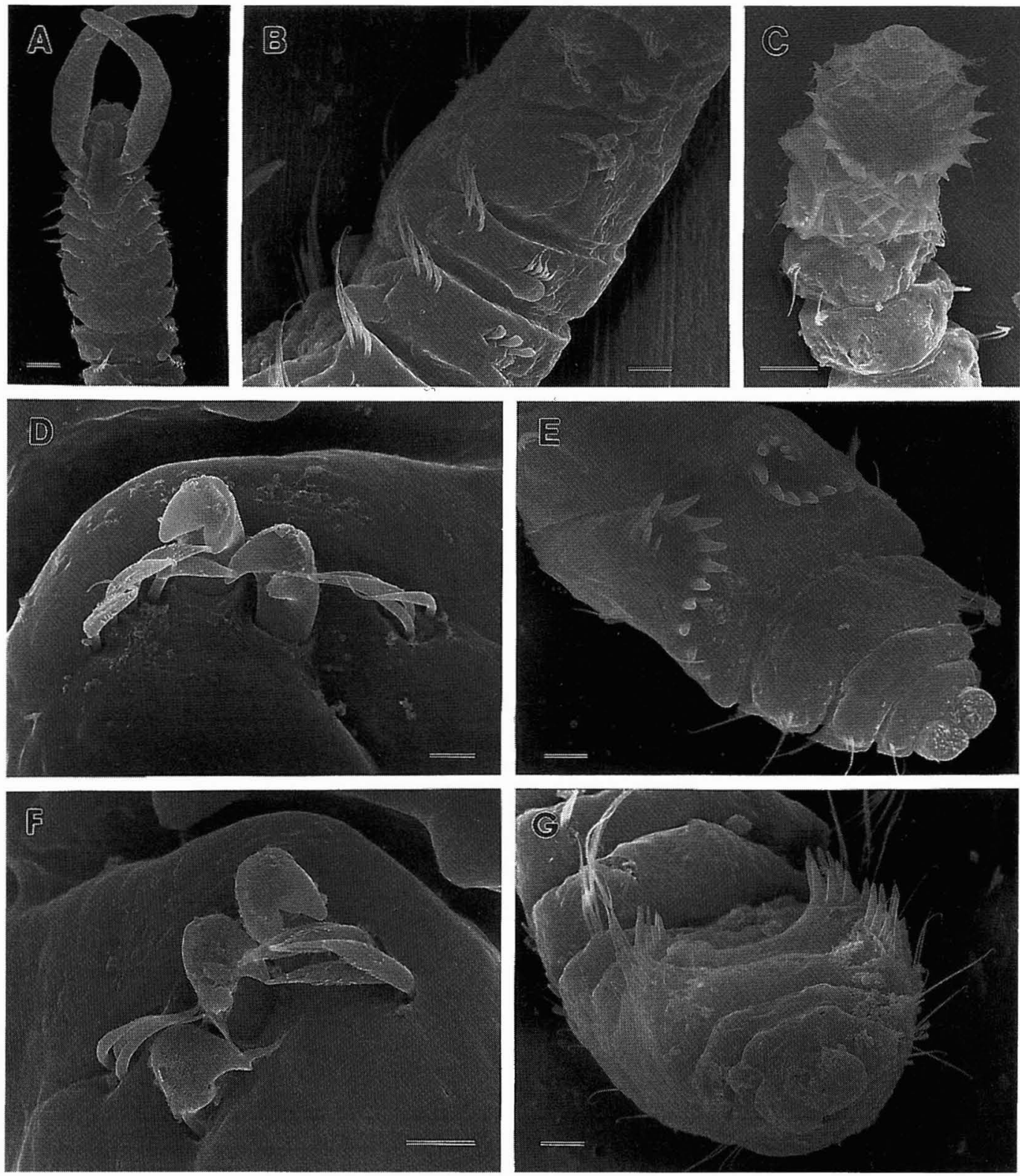

Figure 6. Dipolydora armata (Langerhans) (USNM 187525), SEM micrographs. $A$, Anterior end, dorsal view; $B$, segments 3 to 7, lateral view; $C$, posterior end, dorsal view; $D$, modified spines and noto- and neurosetae of segment 5 , lateral view; $E$, posterior end, dorsal view; $F$, modified spines and noto- and neurosetae of segment 5, lateral view; $G$, posterior end, apical view. Scale: $A, C, 50 \mu \mathrm{m} ; B, E, G, 20 \mu \mathrm{m} ; D, 5 \mu \mathrm{m} ; F, 10 \mu \mathrm{m}$.

Polydora armata Langerhans, 1880:93-94, pl. 4, fig. 5a-c; Fauvel, 1927:55-56, fig. 19a-e; Okuda, 1937:230-231, fig. 10; Hartman, 1941:306; 1969:127, 5 figs.;
Woodwick, 1964:147, fig. 2; Day, 1967: 466-468, fig. 18.2i-j; Kohn and Lloyd, 1973a:381; Rainer, 1973:558, fig. 7; Read, 1975:412-413; Blake and Kudenov, 1978: 
255-256, fig. 43a-g; Hartmann-Schröder, 1979:134, figs. 299-302; Kojima and Imajima, 1982:31-35; Blake, 1983:258-260; Ward, 1987:352-353, fig. 3.II.129.

Polydora monilaris Ehlers, 1905:43-44, pl. 6, figs. 5-14; fide Day (1954).

Dipolydora armata (Langerhans): Blake, 1996: 196-198 [synonomy], fig. 4.36; Lewis, 1998:651-662, figs. 4-8; Sato-Okoshi, 1999:838, appendix 1, appendix 2.

material examined: Philippines: Batangas: 8 spec. (USNM 187521), from Latirus turritus (Gmelin) inhabited by an unidentified hermit crab, Sombrero Island, 5 July 1997; 50+ spec. (AMNH 4247), from Drupa rubusidaeus, Drupella cornus, and Latirus turritus inhabited by Calcinus gaimardii, Dardanus lagopodes, and unidentified hermit crabs, Sombrero Island, 13 July 1997; 10+ spec. (USNM 187522), from Drupa rubusidaeus inhabited by Calcinus latens (Randall), Sepoc Point, 5 July 1997; Oriental Mindoro: $10+$ spec. (USNM 187523), from Drupella cornus inhabited by Calcinus latens, Puerto Galera: Coco Beach, 12 January 1999; 300+ specimens (USNM 187524: 275+ spec.; USNM 187525: 11 spec., on 5 SEM stubs), from Drupella cornus and Cymatium rubeculum (Linnaeus) inhabited by unidentified hermit crabs, Puerto Galera: Big Lalaguna Beach, 19 July 1997; 55+ spec. (AMNH 4248), from Drupella cornus inhabited by Calcinus minutus (Buitendijk) and unidentified hermit crabs, Puerto Galera: Big Lalaguna Beach, 21 July 1997; 40+ spec. (USNM 187526), from Drupella cornus and Cbicoreus palmarosae (Lamarck) inhabited by Calcinus gaimardii and C. latens, Puerto Galera: Big Lalaguna Beach, 31 July 1997; Palawan: 7 spec. (USNM 187527); Aklan: 10+ spec. (usnm 187528), from Drupella cornus inhabited by Calcinus gaimardii, Boracay: Rocky Beach, 12 April 1999; 45+ spec. (UsNm 187529), from Drupella cornus inhabited by Calcinus gaimardii, Boracay: Rocky Beach, 15 April 1999; Cebu: 100+ spec. (USNM 187530), from Astralium sp., Bursa sp., Cantharus sp., Conus sp., Gyrineum gyrinum (Linnaeus), and unidentified gastropod shells inhabited by Calcinus gaimardii, C. latens, Dardanus lagopodes, and unidentified hermit crabs, Olango
Island, 9 July 1997. Indonesia: Bali: $10+$ spec. (USNM 187531), from Conus sp. inhabited by Dardanus lagopodes, Sanur, 5 August 1997; $30+$ spec. (USNM 187532), from Bursa sp., Drupella cornus, and Turbo sp. inhabited by Calcinus gaimardii, C. latens, and Clibanarius englaucus (Ball \& Haig), and live Drupella cornus, Sanur, 6 August 1997; Banjak Island: 10 spec. (USNM 45325), from coral reef limestone platforms, Pulo Melila $\left(2^{\circ} 15^{\prime} \mathrm{N}, 97^{\circ} 25^{\prime} \mathrm{E}\right)$, November 1963, leg. A. J. Kohn. Australia: Point Gellibrand ( $\left.37^{\circ} 52^{\prime} \mathrm{S}, 144^{\circ} 54^{\prime} \mathrm{E}\right)$ : $70+$ spec. (NMv F42881), in shell of Haliotis ruber Leach, 5 April 1997, leg. J. A. Blake and J. D. Kudenov; Tiparra $\left(34^{\circ} 5^{\prime}\right.$ S, $137^{\circ} 29^{\prime}$ E): 1 spec. (NMv F43056), in shell of Haliotis roei Gray, 19 May 1971, leg. S. Shepherd. Caribbean Sea, Barbados, 94 spec., from the hydrocoral Millepora complanata Lamarck, Tropicana reef on the west coast, 11 September 1994, leg. J. Lewis.

Description: Maximum length $3.3 \mathrm{~mm}$ long, $0.2 \mathrm{~mm}$ wide at segment 7; up to 33 segments. Prostomium bifid; caruncle triangular extending from middle to end of segment 2 (Figures $5 A, 6 A$ ); occipital tentacle and eyes absent. Palps extend posteriorly for 10-15 segments (Figures 5A, 6A). In alcohol body opaque white to light tan; no pigmentation present.

Segment 1 with notosetae and longer neurosetae (Figure $6 A$ ). Unilimbate capillary notosetae of segments $2-4,6$, and subsequent segments in two rows (Figure 6B); four to six posteriormost segments containing 9-17 thick acicular spines with straight or curved tip, often in curved arrangement accompanied by two capillary setae (Figures $5 B, C$, $6 C, E, G)$; following segment containing thinner needlelike spines (Figures $5 B, C, 6 G$ ). Unilimbate capillary neurosetae of segments $2-4,6$, and subsequent segments in two rows (Figure 6B); three bidentate hooded hooks begin on segment 7 , up to six in series at segments 8-10; hooks with obtuse angle between main fang and shaft, narrow angle between main fang and apical tooth, no constriction on shaft, with fine bristles covering hood; with capillary companion setae (Figure $10 F)$.

Segment 5 almost twice as large as seg- 
ments 4 and 6 , with two to three spines; posterioventral fascicle of three to four unilimbate capillary neurosetae and anteriodorsal fascicle of three to four geniculate notosetae (Figure 6B,D,F). Major spines bidentate with lateral hood connecting teeth; hood with fine bristles; companion setae absent (Figure $6 D, F)$.

Branchiae begin on segment 7 , attaining full size on segments $8-9$, terminating on segment 11; nototrochs from segment 2 (Figures $5 A, 6 A$ ).

Gizzardlike structure in the digestive tract absent.

Pygidium cuff-shaped with dorsal gap and ventral notch giving appearance of two lobes (Figures $5 B, C, 6 C, E, G$ ).

remarks: The morphology of the Philippine and Indonesian specimens agrees with previous descriptions of this broadly defined species. Blake (1983) indicated that two species might be contained within Dipolydora armata. Specifically, he suggested that a form with thinner posterior spines found in colder latitudes might represent an undescribed species. Although the specimens reported here exhibit thin needlelike spines in one segment following the acicular spines, in all other respects they exhibit the typical morphology of Dipolydora armata. More recently, examination of specimens from Australia, Barbados, and Belize has indicated the existence of several undescribed sibling species (J. A. Blake, pers. comm.; Blake, unpubl. data; Radashevsky, unpubl. data). The specimens reported here may represent an additional undescribed species within the Dipolydora armata complex, but a comprehensive analysis of type material and sibling species is required.

Martin (1996) indicated that Dipolydora armata and D. blakei (Maciolek) may be synonyms, but examination of type material of D. blakei (USNM 81928) showed that the species are distinct. Dipolydora armata differs from D. blakei based on the short triangular caruncle, bidentate major spines with cowling, and cuff-shaped pygidium rather than triangular caruncle extending laterally to the base of the notopodial lamellae on segment 1 , major spines falcate with accessory flange covered by bristles, and larger cup-shaped pygidium.

Lewis (1998) reported on reproduction of Dipolydora armata associated with the hydrozoan Millepora complanata from Barbados. Examination of the Barbados specimens showed that he misidentified peritrichous ciliates (Ciliophora: Oligohymenophorea) attached to the notosetae as spermatophores of Dipolydora armata. The peritrichous ciliates (Cothurnia-like sp.) attached to the notosetae of Dipolydora armata are approximately $50 \mu \mathrm{m}$ in length and have a $30-\mu \mathrm{m}$ smooth stalk. The ciliates are found attached to $16-35 \%$ of Dipolydora armata specimens from Barbados, and worms have 2-12 ciliates attached to the notosetae of the middle body segments (Lewis 1998). In comparison, spermatophores of Polydora cornuta Bosc are about $220 \mu \mathrm{m}$ in length and have a tail approximately $1100 \mu \mathrm{m}$ long covered with short, hairlike projections (Rice 1978). Upon contact with the palps of a female worm the spermatophores break apart and release enclosed sperm (Rice 1978). Spermatophores are probably present in the genus Dipolydora but their production and morphology remain unknown (Rice 1978, Blake and Arnofsky 1999).

ECOLOGY: Dipolydora armata is a common associate of hermit crabs from the Philippines and Indonesia. The worms were found in 1$24 \%$ of the hermit crabs examined from the six provinces sampled in the Philippines $(6.2 \pm 6.3$; total percentage $\pm \mathrm{SD}, n=1578)$. The species is found in burrows penetrating the coralline algal crusts covering live Drupella cornus or gastropod shells inhabited by hermit crabs. Typically the worms burrow through the coralline algae and construct detrital tubes in the space between the shell surface and algal covering. When present, the worms are often abundant, with approximately 35-40 worms per square centimeter, and hundreds of worms are found in a single shell. The worms have been found in 18 gastropods: Astralium sp., Bursa sp., Cantharus sp., Ceritbium tenellum, Chicoreus palmarosae, Conus sp., Coralliophila neritoidea, Cymatium rubeculum, Drupa grossularia, D. rubusidaeus, Drupella sp., D. cornus, D. rugosa, Gyrineum gyrinum, Latirolagena smaragdula (Linnaeus), 
Latirus turritus, Peristernia nassatula, and Turbo sp. inhabited by eight species of hermit crabs: Calcinus gaimardii, C. latens, C. minutus, $C$. pulcher (Forest), Ciliopagurus strigatus, Clibanarius englaucus, Dardanus lagopodes, and $\mathrm{Pa}$ guristes runyanae.

Distribution: United States: California (Blake 1996); New Zealand (Read 1975, Blake 1983); Australia (Blake and Kudenov 1978); Japan: northern limit to Chikura (Sato-Okoshi 1999); Philippines: Batangas, Oriental Mindoro, Palawan, Aklan, Cebu (first record: this paper); Indonesia: Bali (this paper); Europe (Carazzi 1893); South America: Argentina, Chile, Ecuador (Blake 1983); Caribbean Sea: Barbados (Lewis 1998).

\section{Dipolydora socialis (Schmarda, 1861)}

Figures 7, 8

Leucodore socialis Schmarda, 1861:64, figs. $a-c$, pl. 26, fig. 209.

Polydora caeca var. magna Berkeley, 1927:419; Pettibone, 1967:11.

Polydora magna Berkeley \& Berkeley, 1936: 473; 1952:21.

Polydora socialis plena Berkeley \& Berkeley, 1936:468-469; 1952:22; Pettibone, 1967: 11.

Polydora caeca Oersted, sensu Berkeley \& Berkeley, 1936:469; 1952:20-21; non Oersted, 1843; fide Blake (1979b).

Polydora socialis (Schmarda): Hartman, 1941: 310-311, pl. 48, figs. 41-42; 1969:147; Hartmann-Schröder, 1962:137-139, figs. 167-168; 1965:209-211, figs. 200-203; Blake, 1971:20-23, figs. 13-14 [synonomy]; 1975:215, figs. 237-238; 1979b:607609 [synonomy]; 1981:950; 1983:264; Carrasco, 1974:194-196, figs. 27-32; Light, 1977:71; 1978:179-181, fig. 180; Blake and Kudenov, 1978:248-250, fig. 38d-e; Johnson, 1984:6-28 to 6-30, figs. 6-19 and 620; Sato-Okoshi and Okoshi, 1997:486.

Polydora plena Foster, 1971:24-25, figs. 2229.

Polydora neocardalia Hartman, 1961:96-98, pl. 14, figs. 1-4; 1969:141, 2 figs.; Lissner et al., 1986: appendix D; Steinhauer and Imamura, 1990: F-1; fide Blake (1996).
Dipolydora socialis (Schmarda): Blake, 1996: 189-192, fig. 4.34 [synonomy].

MATERIAL EXAMINed: Philippines: Bataan: 1 spec. (USNM 187533), from Cantharus undosus (Linnaeus) inhabited by Calcinus gaimardii, Mabayo, 21 February 1999; Batangas: 3 spec. (amnH 4249), from Drupa rubusidaeus inhabited by Dardanus lagopodes, Anilao, 13 February 1999; 13 spec. (USNM 187534: 10 spec., USNM 187535: 3 spec., on 3 SEM stubs), from Drupa rubusidaeus, Drupella cornus, and an unidentified gastropod shell inhabited by Calcinus minutus and unidentified hermit crabs, Sombrero Island, 13 July 1997; 1 spec. (UsNm 187536), from Drupella cornus inhabited by Calcinus minutus, Sombrero Island, 30 January 1999; Palawan: 1 spec. (UsNM 187537) from Drupella rugosa inhabited by Paguristes runyanae, Magbautoc Island, 16 March 1999. Australia: Port Phillip Bay: 5 spec. (NMv F43159), from silt/sand, Geelong Arm (38 $\left.2.3^{\prime} \mathrm{S}, 144^{\circ} 34.5^{\prime} \mathrm{E}\right), 18$ November 1971, leg. Marine Pollution Studies Group.

description: Largest Philippine specimen measured $7.0 \mathrm{~mm}$ long, $0.4 \mathrm{~mm}$ wide at segment 7; 56 segments. Prostomium strongly incised on anterior margin; caruncle extending to segments 3-5; occipital tentacle and eyes absent (Figures $7 A, 8 A$ ). Palps extending posteriorly to segments $11-15$; with dusky black pigmentation on ventral side on some specimens (Figure 7A). Color in alcohol opaque white; no body pigmentation.

Segment 1 with noto- and neurosetae and large notopodial lobes (Figures 7A, 8A). Winged capillary notosetae of segments 2-4, 6 , and subsequent segments arranged in three rows; no specialized posterior spines. Winged capillary neurosetae of segments $2-4,6$, and subsequent segments in two rows; two or three bidentate hooded hooks from segment 7 , up to five in series at segment 11 , accompanied by one or two capillary setae on segments 7-10; hooks curved with obtuse angle between main fang and shaft, narrow angle between main fang and apical tooth, without constriction on shaft (Figure $7 E$ ).

Segment 5 with posterioventral fascicle of four geniculate neurosetae and anteriodorsal fascicle of two or three geniculate notosetae; 


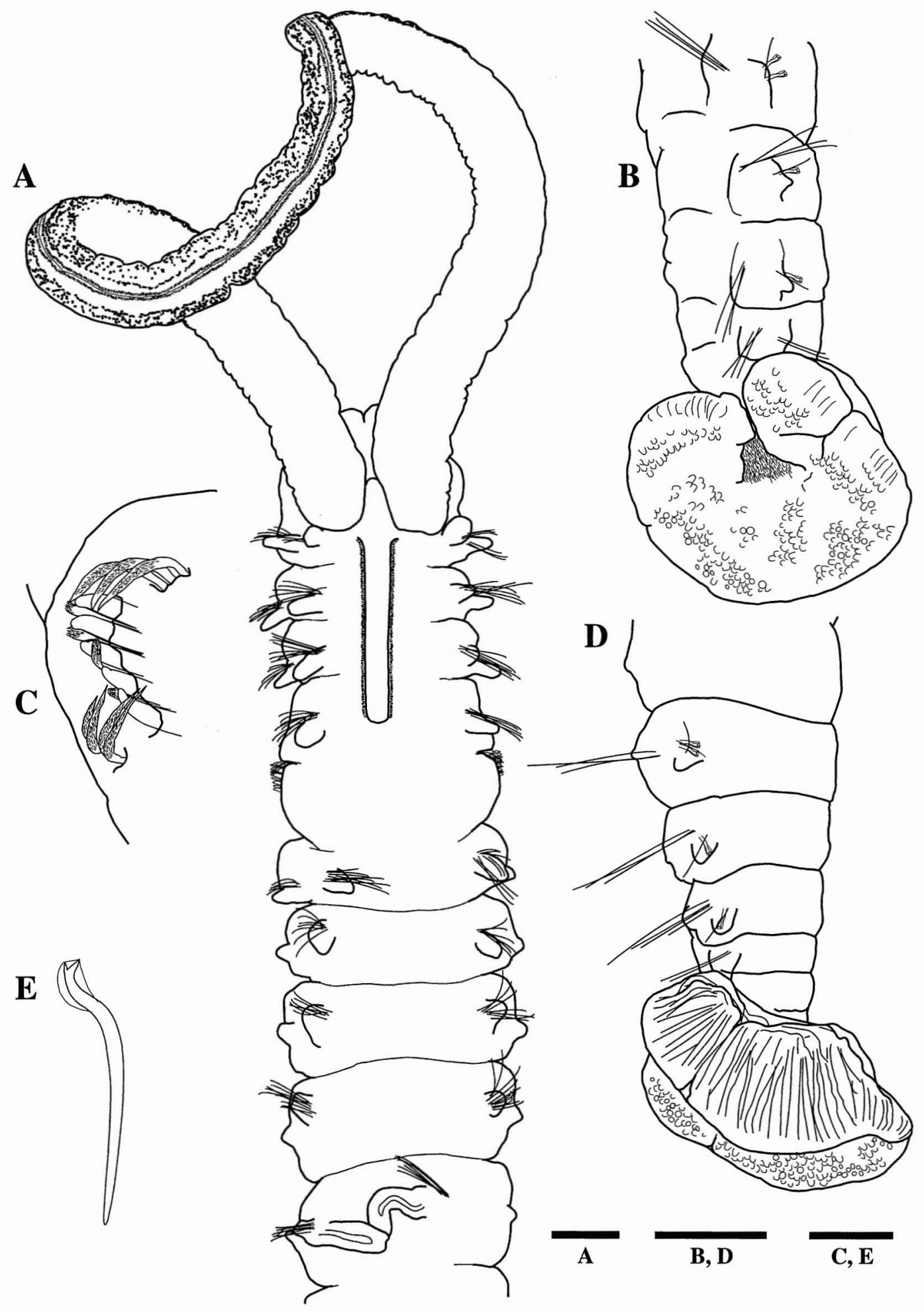

Figure 7. Dipolydora socialis (Schmarda) (USNM 187533). $A$, Anterior end, dorsal view; $B$, posterior end, dorsolateral view; $C$, falcate spines and companion setae of fifth segment, lateral view; $D$, posterior end, lateral view; $E$, bidentate hooded hook from anterior segment. Scale: $A, B, D, 100 \mu \mathrm{m} ; C, E, 30 \mu \mathrm{m}$. 

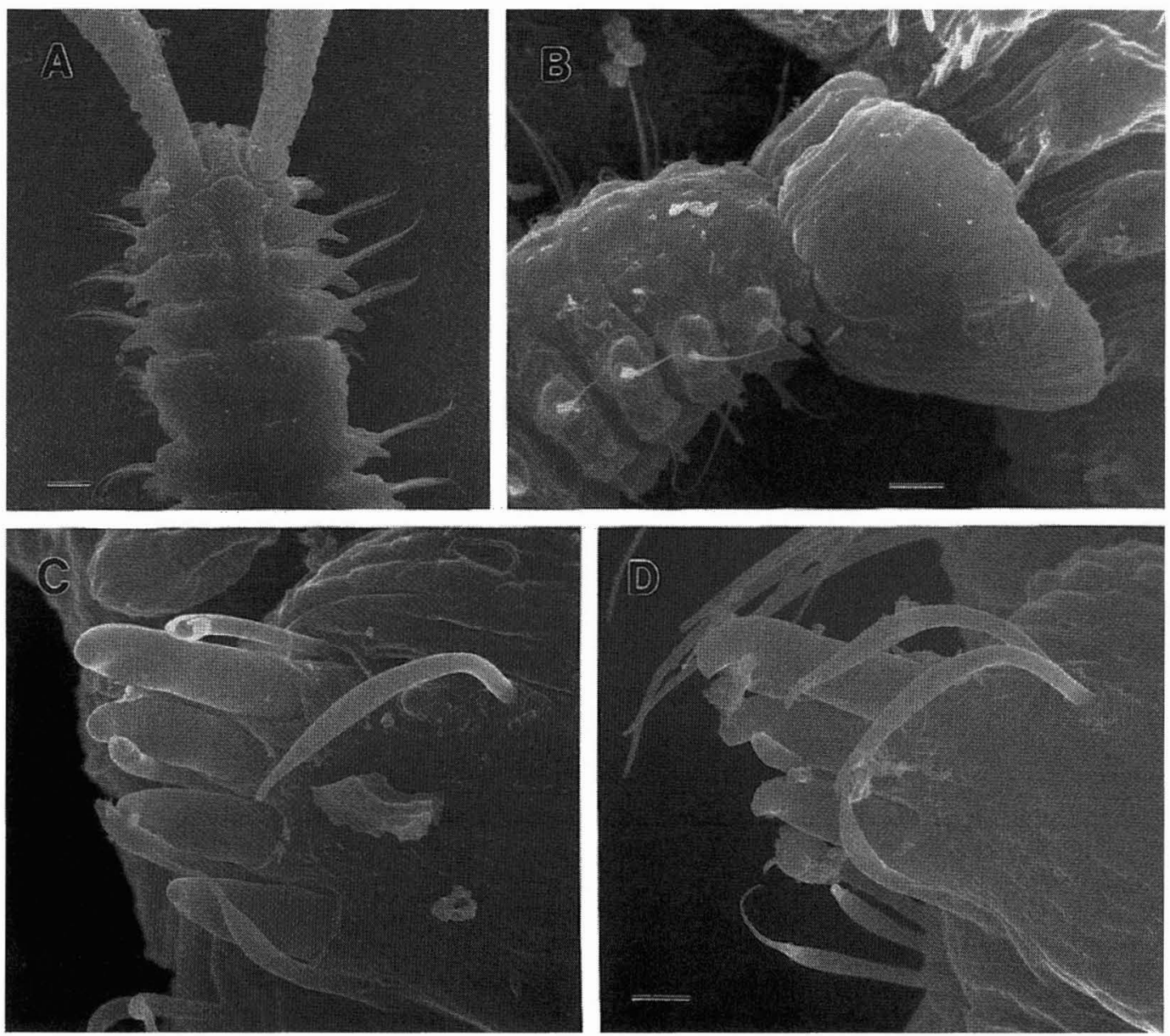

Figure 8. Dipolydora socialis (Schmarda) (USNM 187535), SEM micrographs. $A$, Anterior end, dorsal view; $B$, posterior end, dorsolateral view; $C$, falcate spines and companion setae of fifth segment, dorsal view; $D$, falcate spines and companion setae of fifth segment, dorsal view. Scale: $A, 50 \mu \mathrm{m} ; B, 20 \mu \mathrm{m} ; C, D, 5 \mu \mathrm{m}$.

slightly curved row of five exposed major spines alternating with pennoned companion setae (Figures $7 C, 8 C, D$ ). Major spines falcate, with subterminal protuberance (Figures $7 C, 8 C, D)$.

Branchiae begin on segments 8-10; reaching posterior one-third of body.

Gizzardlike structure apparent in some specimens at segments 14-18.

Pygidium with large ventral lobe and two smaller dorsal lobes; dorsal lobes inconspicuous in some specimens (Figures $7 B, D$, $8 B)$.
REMARKs: The Philippine specimens agree well with recent descriptions of Dipolydora socialis (Blake 1996). However, the specimens are mostly smaller than those previously recorded, although Blake and Kudenov (1978) also found smaller specimens in collections from Australia. Considerable debate exists over the burrowing activity of Dipolydora socialis. The species has been documented to construct burrows in soft bottom sediments and calcareous substrata, including gastropod shells inhabited by hermit crabs (Blake 1971, 1981; J.D.W., unpubl. data). However, Rada- 
shevsky (1993) and Sato-Okoshi and Okoshi (1997) considered the species to be a nonburrower restricted to soft bottom areas.

The gross morphology of the gizzardlike structure of the anterior portion of the digestive tract has been described in considerable detail for Dipolydora socialis and other related species (Blake 1971), but the function of the structure has not been investigated. In the description of Pygospio muscularis, Ward (1981) proposed that the structure aids in the removal of bacterial and algal films attached to sand grains. Histological and behavioral feeding studies of species possessing the gizzardlike structure are required to determine its functional significance.

ECOlOgY: In this study Dipolydora socialis was found in sediment tubes constructed within the crevices of damaged gastropod shells (Cantharus undosus, Drupa rubusidaeus, Drupella cornus, and D. rugosa) inhabited by hermit crabs (Calcinus gaimardii, C. minutus, Dardanus lagopodes, and Paguristes runyanae). Three specimens were found with peritrichous ciliates (Ciliophora: Oligohymenophorea) attached to the notosetae of approximately four to six segments, with one ciliate per fascicle. Additional reports of peritrichous ciliates associated with spionid polychaetes include Boccardiella magniovata (Read), Polydora neocaeca Williams \& Radashevsky (Read 1975, Williams and Radashevsky 1999), and Dipolydora armata (see previous Remarks section). Williams and Radashevsky (1999) used SEM to examine the stalks of peritrichs attached to the hooded hooks of Polydora neocaeca. Little is known about the association between peritrichs and polychaete hosts, but the peritrichs may benefit by extending between the branchiae of the worms and feeding within the flow of water drawn through the burrow.

distribution: Mexico (Blake 1981); United States: east and west coasts (Blake 1971, 1996); Canada: Vancouver Island (SatoOkoshi and Okoshi 1997); New Zealand (Read 1975); Australia (Blake and Kudenov 1978); Philippines: Bataan, Batangas, Palawan (first record: this paper); Falkland Islands (Blake 1983); South America: Argentina, Chile, Ecuador (Blake 1983).
Dipolydora tridenticulata (Woodwick, 1964) Figures 9, 10

Polydora tridenticulata Woodwick, 1964:153157, fig. 4(1-5); Ward, 1987:354-355, fig. 3.II.132.

Dipolydora tridenticulata (Woodwick): Blake, 1996:186.

Material examined: Philippines: Batangas: 3 spec. (USNM 187538: 1 spec.; USNM 187539: 2 spec., on 3 SEM stubs), from Bursa granularis (Röding), inhabited by Calcinus minutus and Dardanus lagopodes, Anilao, 13 February 1999; 8 spec. (USNM 187540), from Drupella cornus inhabited by Dardanus lagopodes and dead bivalve shells, Sombrero Island, 30 January 1999; 6 spec. (AMNH 4250: 5 spec.; USNM 187541: 1 spec., on SEM stub), from Drupa rubusidaeus inhabited by Calcinus gaimardii and Dardanus lagopodes, Sombrero Island, 13 July 1997; Oriental Mindoro: 2 spec. (USNM 187542: 1 spec.; USNM 187543: 1 spec., on SEM stub), from Drupella cornus inhabited by Calcinus minutus, Puerto Galera: Big Lalaguna Beach, 21 July 1997; 20 spec. (USNM 187544: 15 spec.; USNM 187545: 5 spec., on 7 SEM stubs), from Drupa sp., Drupella cornus, Terebra sp., and an unidentified gastropod shell inhabited by Calcinus gaimardii, C. minutus, and C. latens, Puerto Galera: Big Lalaguna Beach, 31 July 1997. Marshall Islands: Eniwetok Atoll: holotype (USNM 32612), burrowing in coral rock, Rigili, 29 August 1956, leg. D. J. Reish.

DESCRIPTION: Largest Philippine specimen $3.1 \mathrm{~mm}$ long, $0.3 \mathrm{~mm}$ wide at segment 7; 69 segments. Prostomium slightly incised; broad caruncle extending to segments 3-4; occipital tentacle absent; eyes deeply embedded and irregularly shaped or eyes absent (Figures 9A, 10A). Palps extending posteriorly to segment 8 . In alcohol body opaque white; no pigmentation.

Segment 1 with noto- and neurosetae (Figures 9A, 10A). Winged capillary notosetae of segments $2-4,6$, and subsequent segments in three rows; no specialized posterior spines. Winged capillary neurosetae of segments $2-4,6$, and subsequent segments in two rows; one to three bidentate hooded 


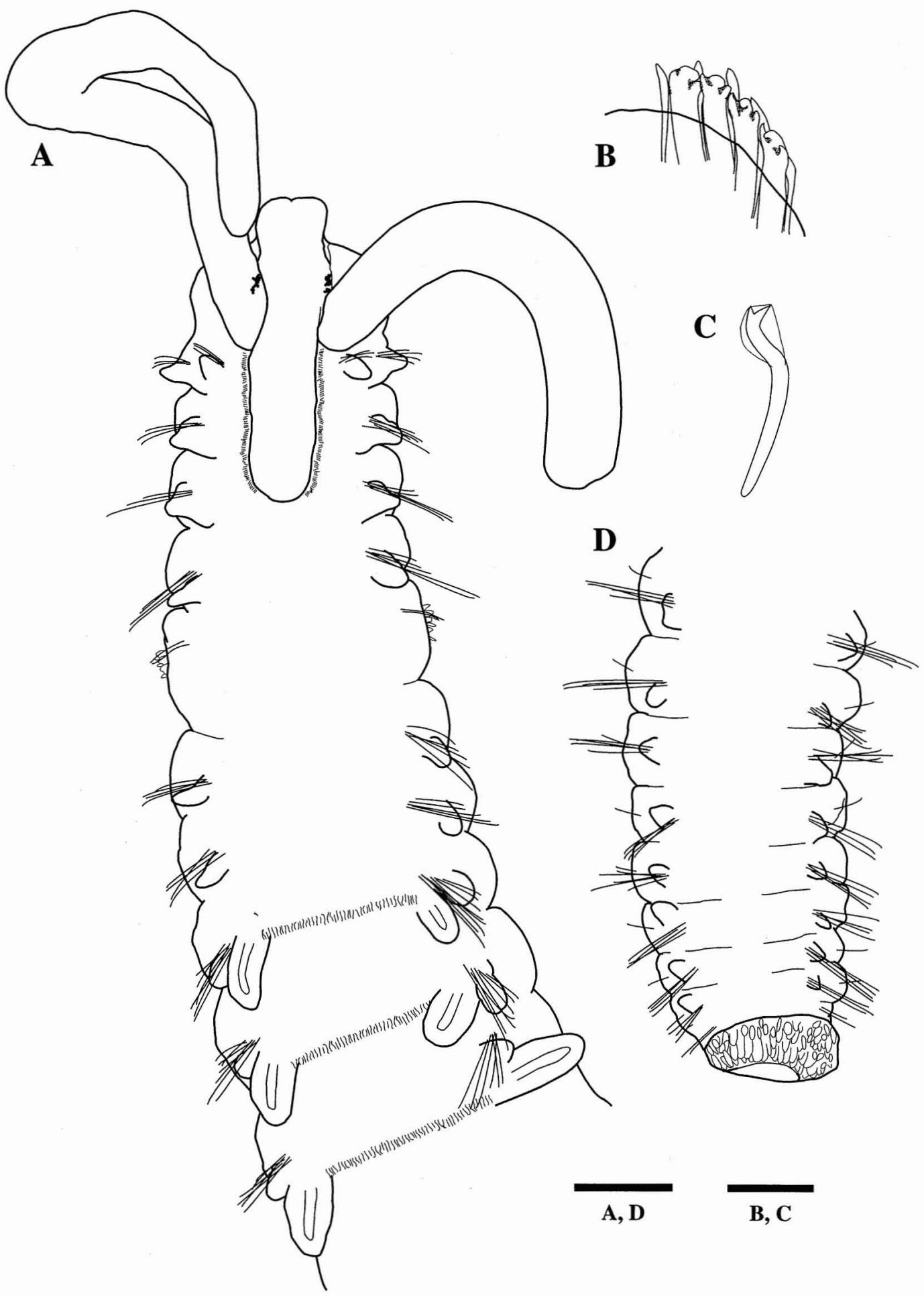

Figure 9. Dipolydora tridenticulata (Woodwick) (USNM 187540). $A$, Anterior end, dorsal view; $B$, spines and companion setae of fifth segment, dorsal view; $C$, bidentate hooded hook from anterior segment; $D$, posterior end, dorsal view. Scale: $A, D, 100 \mu \mathrm{m} ; B, C, 30 \mu \mathrm{m}$. 

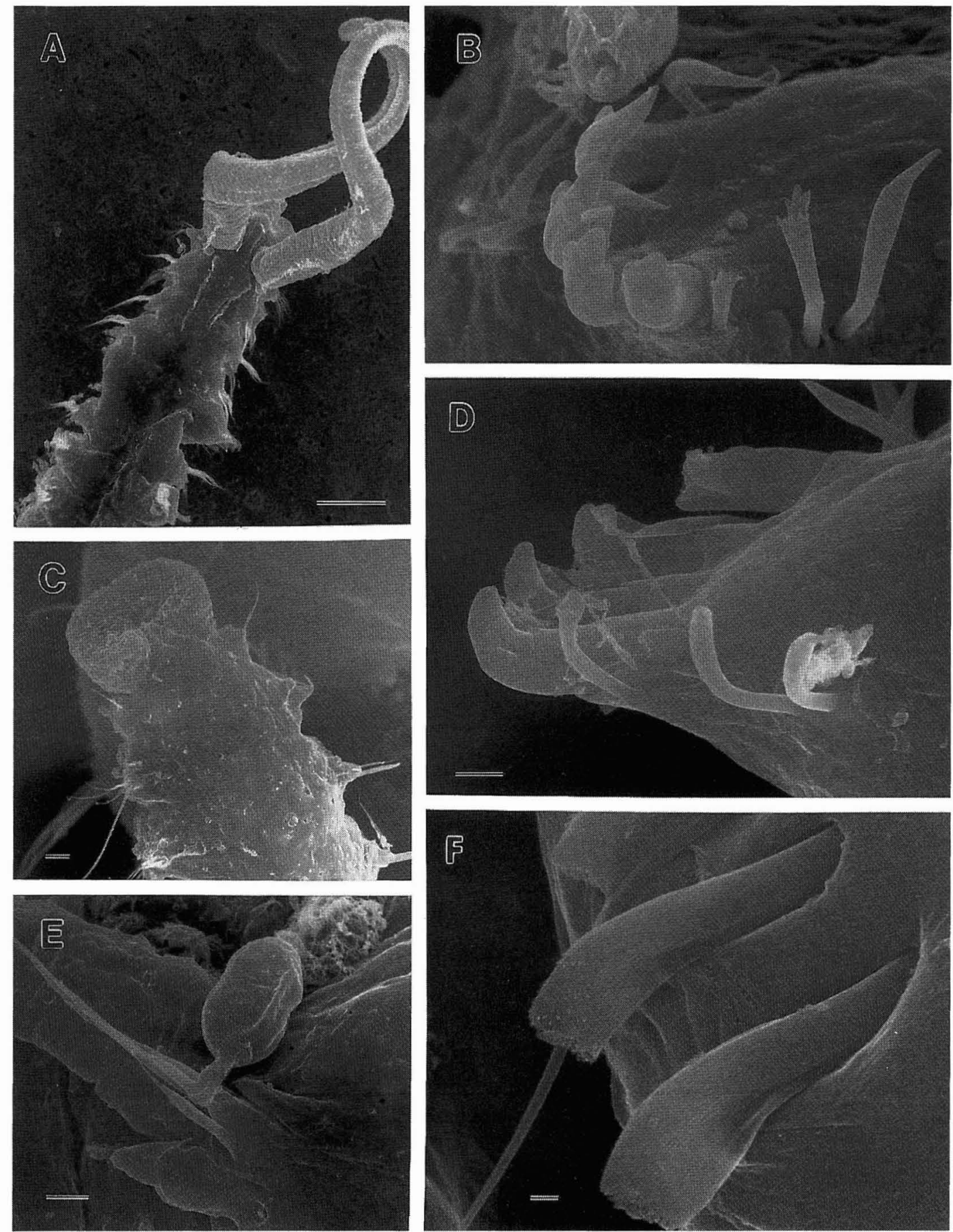

FIGURE 10. Dipolydora tridenticulata (Woodwick) (USNM 187539) (A-D), (USNM 187541) (B), (USNM 187545) $(C, E)$ and Dipolydora armata (Langerhans) (USNM 187525) (F), SEM micrographs. $A$, Anterior end, dorsal view; $B$, spines and companion setae of fifth segment, dorsolateral view; $C$, posterior end, dorsal view; $D$, spines and companion setae of fifth segment, dorsal view; $E$, peritrichous ciliate attached to notosetae; $F$, bidentate hooded hooks of anterior segment. Scale: $A, 100 \mu \mathrm{m} ; B, D, 5 \mu \mathrm{m} ; C, E, 10 \mu \mathrm{m} ; F, 1 \mu \mathrm{m}$. 
hooks from segment 7 , up to five in series at segment 15 , accompanied by one capillary seta on segments 7-9; hooks with obtuse angle between main fang and shaft, narrow angle between main fang and apical tooth, no constriction on shaft (Figure 9C).

Segment 5 with posterioventral fascicle of four winged neurosetae and anteriodorsal fascicle of two geniculate notosetae; slightly curved row of three to five exposed major spines alternating with pennoned companion setae (Figures 9B, 10B,D). Major spines falcate with two lateral teeth (Figures $9 B$, $10 B, D)$. Teeth of unworn posterior spines curved with a sharp point; one tooth extends beyond main fang of spine, other tooth below main fang; worn anterior spines with rounded teeth below main fang (Figures $9 B, 10 B, D$ ).

Branchiae begin on segments $8-10$; attaining full size at segment 11 ; terminating on segments 15-20, nototrochs between branchiae.

Gizzardlike structure absent in digestive tract.

Pygidium small, glandular cuff-shaped with dorsal notch (Figures 9C, 10E).

REMARKs: Dipolydora tridenticulata belongs to the D. giardi group of six species known to burrow into calcareous substrata (Blake 1996). The lateral teeth of the major spines are worn on the anterior spines (Figures $9 B$, $10 B, D)$, and, as indicated by Woodwick (1964), the tridentate morphology of the spines is not apparent if care is not taken to view them from various angles. However, SEM shows that the two lateral teeth are observable even in worn spines and are best seen in lateral view (Figure $10 B$ ).

ecology: Dipolydora tridenticulata is a burrower found in gastropod shells (Bursa granularis, Drupa sp., D. rubusidaeus, Drupella cornus, and Terebra sp.) inhabited by hermit crabs (Calcinus gaimardii, C. latens, C. minutus, and Dardanus lagopodes). The species has also been found in dead bivalve shells. Peritrichous ciliates were found attached by a short stalk to the notosetae of anterior segments in three specimens. The anterior end of the ciliates extends to a position between the branchiae of the worms (Figure 10E).
Only one ciliate was found per fascicle of notosetae. See discussion on ecology of $D i$ polydora socialis for additional references to peritrich/spionid associations.

distribution: Hawai'i (Ward 1987); Marshall Islands (Woodwick 1964); Philippines: Batangas: Oriental Mindoro (first record: this paper).

Genus Polydora Bosc, 1802, sensu Blake, 1996

Polydora Bosc, 1802:151. Type species: Polydora cornuta Bosc, 1802, by monotypy.

Leucodore Johnston, 1838:66. Type species: Leucodore ciliatus Johnston, 1838, by monotypy; fide Blake and Maciolek (1987).

Leipoceras Möbius, 1874:254. Type species: Leipoceras uviferum Möbius, 1874, by monotypy; fide Blake and Maciolek (1987).

Protopolydora Czerniavsky, 1881:360. Type species: Polydora bamata Langerhans, 1880, by original designation. Homonym of Polydora hamata Webster, 1879, renamed Polydora posthamata Jones, 1962.

DiAgNosis: Prostomium with anterior incision or rounded; caruncle extending posteriorly, surrounded by cilia of nuchal organ. Segment 1 without notosetae. Segment 5 modified with one type of major spine in a single curved row, with or without companion setae; juveniles may possess large, falcate major spines that are replaced by subsequent spines. Posterior notopodial spines present or absent. Bidentate hooded hooks begin on segments 7-14, main fang at approximately right angle to shaft, wide angle between main fang and apical tooth, with constriction on shaft. Branchiae begin posterior to segment 5 . Pygidium variable: cuff-shaped, cup-shaped with dorsal gap, lobed, scoop-shaped, or with digitiform cirri. Anterior portion of digestive tract lacks gizzardlike structure.

Polydora sp. A

Figure 11

material examined: Philippines: Oriental Mindoro: 1 spec. (USNM 187546), from Coralliophila sp. inhabited by Calcinus gai- 


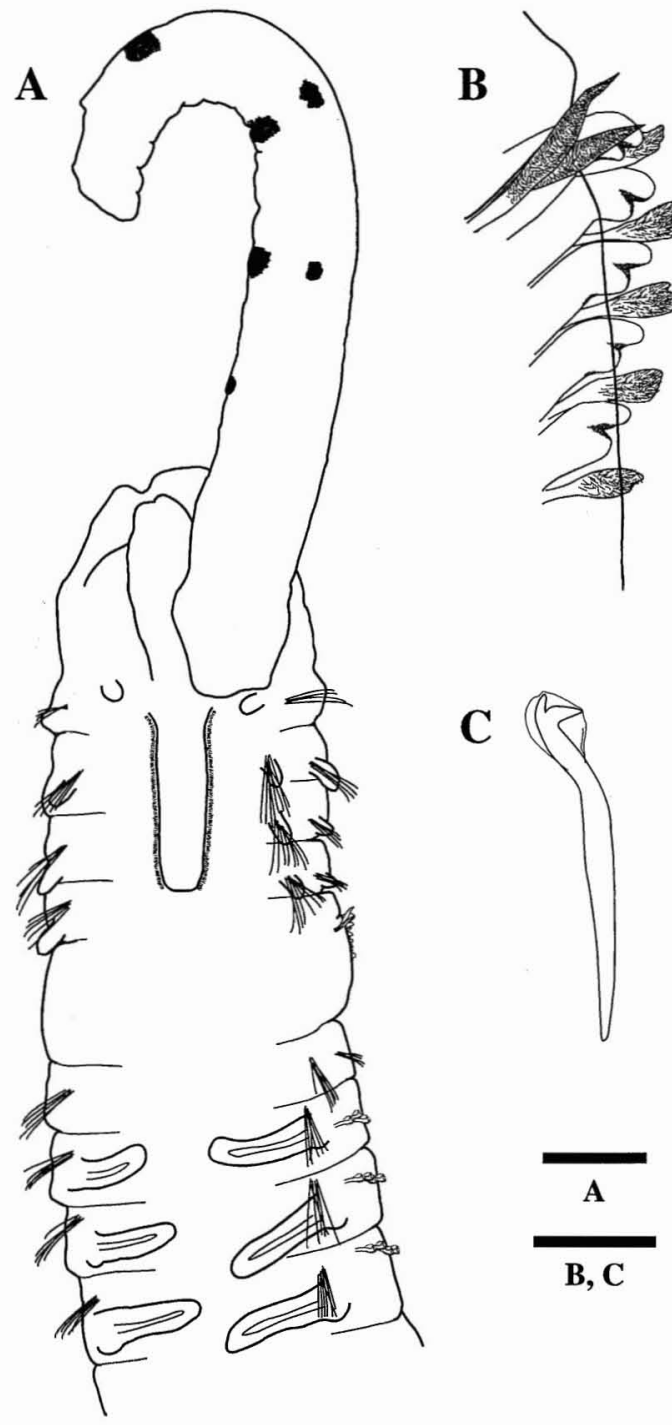

Figure 11. Polydora sp. A (USNM 187545). $A$, Anterior end, dorsal view; $B$, spines and companion setae of fifth segment, dorsal view; $C$, bidentate hooded hook from anterior segment. Scale: $A, 200 \mu \mathrm{m} ; B, C, 30 \mu \mathrm{m}$.

mardii, Puerto Galera: Big Lalaguna Beach, 31 July 1997.

DESCRIPTION: Specimen broken, lacking posterior end; $7.9 \mathrm{~mm}$ long, $0.3 \mathrm{~mm}$ wide at segment 7; 48 segments. Prostomium slightly bifid; caruncle terminating at end of segment 3 ; eyes and occipital tentacle absent (Figure
$11 A$ ). In alcohol body opaque white to light tan, palps crossed with distinct bars of black pigmentation (Figure 11A).

Segment 1 with neurosetae, without notosetae, with weakly developed notopodial lobes. Winged capillary notosetae of segments 2-4, 6, and subsequent segments arranged in three successive rows; no specialized posterior notosetae. Winged capillary neurosetae of segments 2-4, 6, and subsequent segments arranged in two vertical rows; five bidentate hooded hooks begin on segment 7, not accompanied by capillaries, up to eight in series at segment 23; hooks with approximately right angle between main fang and shaft, wide angle between main fang and apical tooth, with constriction on shaft (Figure $11 C$ ).

Segment 5 almost twice as large as segments 4 and 6, with slightly curved row of five exposed major spines alternating with pennoned companion setae; with posterioventral fascicle of four winged capillary neurosetae; anteriodorsal fascicle of two geniculate notosetae. Major spines falcate, with rounded, lateral tooth (Figure 11B).

Branchiae begin on segment 7; attaining full size at 12 .

Pygidium unknown.

Remarks: Polydora sp. A belongs to the Polydora ciliata/websteri group. The species most closely resembles Polydora sp. (Blake 1996), Polydora sp. (Caceres-Martinez et al. 1999), Polydora sp. (Sato-Okoshi 1999), P. agassizi Claparède, $P$. cf. agassizi (Radashevsky and Hsieh 2000a), and P. limicola Annenkova in having palps crossed by black bars, caruncle length, and major spine morphology. Lack of a posterior end and pygidium precludes determination of the species. Polydora possessing palps with distinct bars or blotches of black pigment have recently been reviewed (Williams and Radashevsky 1999, Radashevsky and Hsieh 2000a).

ECOLOGY: The species was found associated with the gastropod shell Coralliophila sp. inhabited by the hermit crab Calcinus gaimardii. It is unknown whether Polydora sp. A is a shell burrower or occupied a mud tube in the crevices of the gastropod shell. 
Polydora umangivora Williams, n. sp.

Figures 12, 13

holotype: Philippines: Batangas (USNM 187553), from Thais mancinella inhabited by Dardanus lagopodes, Sombrero Island, 30 January 1999.

Other material EXAMINed: Philippines: Bataan: 31 paratypes (AMNH 4251), from Cantharus undosus, Coralliopbila neritoidea (Lamarck), Cymatium sp., Cypraea sp., Latirolagena smaragdula, Latirus polygonus (Gmelin), L. turritus, and an unidentified gastropod shell inhabited by Calcinus gaimardii, C. minutus, and Dardanus lagopodes, Mabayo, 21 February 1999; 1 paratype (USNM 187547), from an unidentified gastropod shell inhabited by Diogenes sp., Morong, 6 February 1999; 7 paratypes (AMNH 4252), from Cantharus undosus, Coralliophila neritoidea, Latirolagena smaragdula, and an unidentified gastropod shell inhabited by Calcinus gaimardii and C. minutus, Morong, 28 February 1999; 1 paratype (USNM 187548), from Cantharus undosus inhabited by Calcinus gaimardii, Morong, 25 April 1999; Batangas: 6 paratypes (USNM 187549), from Terebra sp. inhabited by an unidentified hermit crab, Anilao, 20 June 1997; 31 paratypes (USNM 187550), from Latirus turritus, Pisania fasciculata (Reeve), and an unidentified gastropod shell inhabited by Clibanarius sp. and Dardanus sp., Anilao, 28 June 1997; 14 paratypes (USNM 187551), from Bursa granularis, Drupa rubusidaeus, Drupella cornus, D. rugosa, Drupella sp., Gyrineum sp., Latirus turritus, Thais mancinella (Linnaeus), and an unidentified gastropod shell inhabited by Calcinus gaimardii, C. minutus, C. pulcher, and Dardanus lagopodes, Anilao, 13 February 1999; 3 paratypes (USNM 187552), from Drupella cornus and Thais mancinella inhabited by Calcinus minutus and Dardanus sp., Sombrero Island, 13 July 1997; 4 paratypes (USNM 187554), from Chicoreus palmarosae, Drupella cornus, and Thais mancinella inhabited by Calcinus latens and Dardanus lagopodes, Sombrero Island, 30 January 1999; 3 paratypes (USNM 187555), from Conus sp., Drupella cornus, and Latirus turritus inhabited by Calcinus latens and an unidentified hermit crab, Sepoc Point, 5 July 1997; Oriental Mindoro: 7 paratypes
(USNM 187556), from Coralliophila neritoidea, Drupella cornus, and Latirolagena smaragdula inhabited by Calcinus gaimardii, Puerto Galera: Coco Beach, 12 January 1999; 3 paratypes (USNM 187557), from Drupella cornus and D. rugosa inhabited by Calcinus gaimardii and C. latens, Puerto Galera: Coco Beach, 14 January 1999; 2 paratypes (USNM 187558), from Drupella cornus inhabited by Calcinus gaimardii, Puerto Galera: Coco Beach, 15 January 1999; 1 paratype (USNM 187559), from Drupella cornus inhabited by Calcinus gaimardii, Puerto Galera: Big Lalaguna Beach, 19 July 1997; 2 paratypes (USNM 187560), from Cymatium rubeculum inhabited by Calcinus gaimardii and Clibanarius sp., $\mathrm{Pu}-$ erto Galera: Big Lalaguna Beach, 21 July 1997; 11 paratypes (USNM 187561), from Drupella cornus, Latirolagena smaragdula, Turbo sp., and unidentified gastropod shells inhabited by Calcinus gaimardii and Clibanarius englaucus, Puerto Galera: Big Lalaguna Beach, 31 July 1997; 6 paratypes (USNM 187562), from Coralliophila neritoidea, Drupella cornus, Strombus labiatus labiatus Röding, and an unidentified gastropod shell inhabited by Calcinus gaimardii, $C$. latens, $C$. minutus, and an unidentified hermit crab, Puerto Galera: Big Lalaguna Beach, 28 March 1999; 2 paratypes (USNM 187563), from Drupella cornus and an unidentified gastropod shell inhabited by Calcinus gaimardii, Bayanan Beach, 13 January 1999; Aklan: 3 paratypes (USNM 187564), from Drupella cornus and an unidentified gastropod shell inhabited by Calcinus gaimardii and $C$. latens, Boracay: Diniwid Beach, 13 April 1999; 2 paratypes (USNM 187565), from Cantharus undosus and Drupella rugosa inhabited by Calcinus latens, Boracay: Rocky Beach, 12 April 1999; 5 paratypes (USNM 187566), from Coralliopbila neritoidea, Drupa sp., Drupella cornus, D. rugosa, and an unidentified gastropod shell inhabited by Calcinus gaimardii, C. latens, and C. minutus, Boracay: Rocky Beach, 15 April 1999; Palawan: 5 paratypes (USNM 187567), from Drupella rugosa and an unidentified gastropod shell inhabited by Paguristes runyanae, Magbautoc Island, 16 March 1999; 3 paratypes (USNm 187568), Conus sp. and Drupella rugosa inhabited by Calcinus latens and D. lagopodes, Apulit Island, 15 March 1999; 


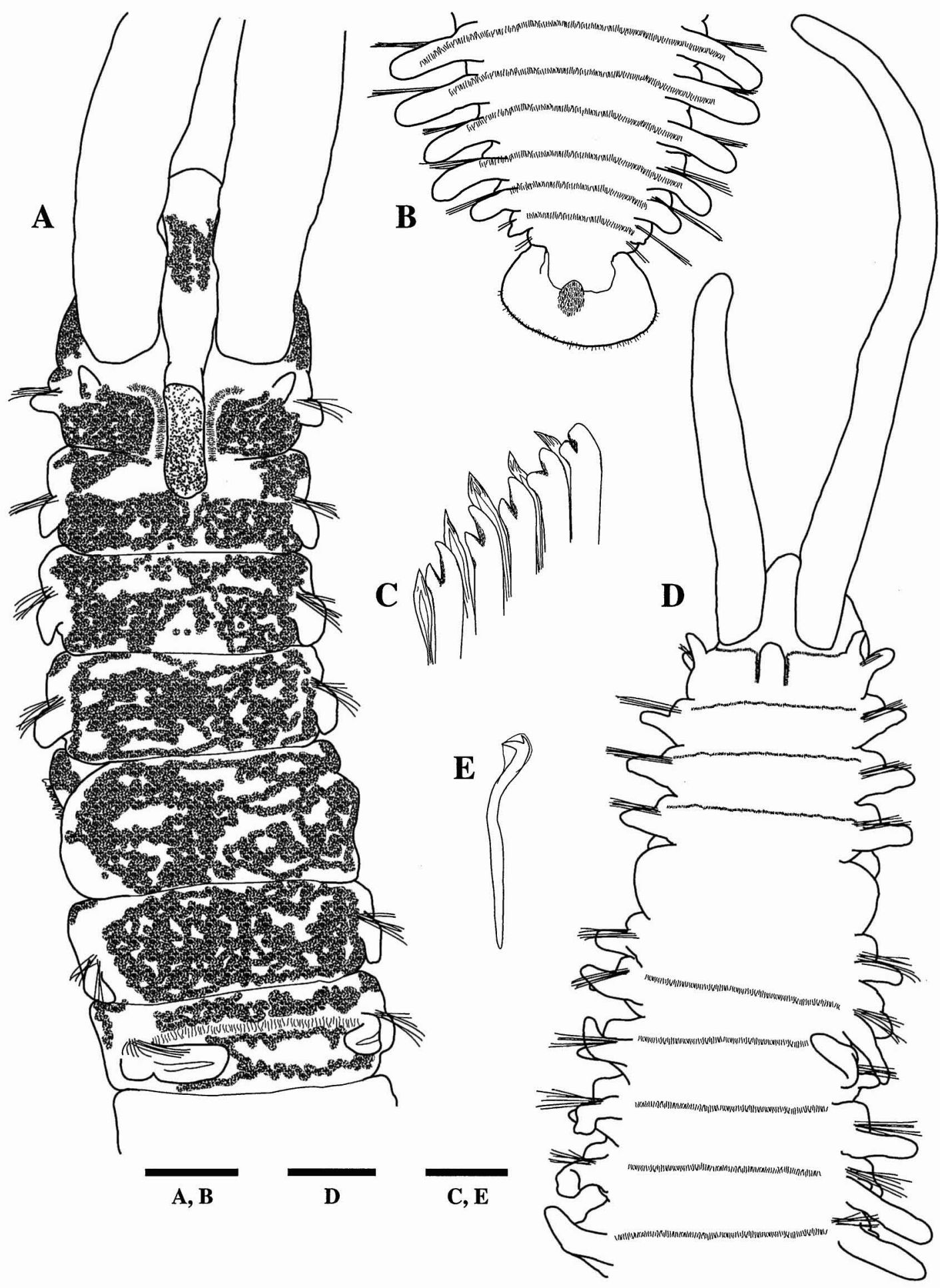

Figure 12. Polydora umangivora, n. sp.: holotype (UsNm 187553) $(B, D)$ and paratype (UsNm 187570) $(A, C, E) . A$, Anterior end, dorsal view; $B$, posterior end, dorsal view; $C$, spines and companion setae of fifth segment, dorsal view; $D$, anterior end, dorsal view; $E$, bidentate hooded hook from anterior segment. Scale: $A, B, 200 \mu \mathrm{m} ; D, 300 \mu \mathrm{m} ; C, E$, $30 \mu \mathrm{m}$. 
1 paratype (USNM 187569), from Cerithium tellenum Sowerby inhabited by Paguristes runyanae, Apulit Island, 17 March 1999; Cebu: 38 paratypes (USNM 187570: 35 paratypes; USNM 187571: 3 paratypes, on 6 SEM stubs), from Astralium rbodostoma (Lamarck), Bursa sp., Cantharus sp., Conus sp., Drupella cornus, Strombus sp., Turbo sp., and an unidentified gastropod shell inhabited by Calcinus gaimardii, C. latens, Clibanarius englaucus, Dardanus lagopodes, and an unidentified hermit crab, Olango Island, 9 July 1997. Indonesia: Bali: 2 paratypes (USNM 187572), from Bursa sp. and Drupella cornus inhabited by Calcinus gaimardii, Sanur, 6 August 1997.

DESCRIPTION: $31.7 \mathrm{~mm}$ long, $0.8 \mathrm{~mm}$ wide at segment 7; 186 segments. Ovigerous female with ova in segments 27-107. Prostomium rounded to slightly indented when viewed ventrally; caruncle short, terminating on segments 1-2; occipital tentacle and eyes absent (Figures 12A,D, 13A,C). Palps extend posteriorly for 10-12 segments. In life, palps and body are pale yellow to orange; no pigmentation present. After preservation color usually dark yellow/orange on dorsal and ventral sides of prostomium, peristomium, and all segments (Figure 12A).

Segment 1 with neurosetae, without notosetae, with weakly developed notopodial lobes (Figure $13 A, C$ ). Winged capillary notosetae of segments 2-4, 6, and subsequent segments in three rows (Figure 13D); no specialized posterior notosetae. Winged capillary neurosetae of segments 2-4, 6, and subsequent segments in two rows (Figure 13D); five bidentate hooded hooks begin on segment 7 , up to 11 in series at segment 23 , not accompanied by capillaries; hooks with approximately right angle between main fang and shaft, wide angle between main fang and apical tooth, with constriction on shaft, with fine bristles on hood (Figures 12E, 13F).

Segment 5 almost twice as large as segments 4 and 6, with slightly curved row of five exposed major spines and one developing spine alternating with pennoned companion setae; posterioventral fascicle of winged neurosetae; notosetae absent (Figure $13 D, E$ ). Major spines falcate, with lateral tooth (Figures $12 C, 13 D, E)$.
Branchiae begin on segment 7 , continuing to terminal segments of body; attaining full size at segment 12 . Dorsal ciliary bands on segments $1-4$ and 7 to terminal segments (Figures 12D, 13A,C).

Pygidium broad cup-shaped with nonmotile cilia on rim of pygidium (Figures $12 B$, $13 B)$.

ETYMOLOGY: The species is named after its behavior of ingesting (vora, to eat in Greek) the embryos of host hermit crabs (umang, hermit crab in the Ilokano language of the Philippines).

Remarks: Polydora umangivora belongs to the Polydora ciliata/websteri group and most closely resembles $P$. woodwicki Blake \& $\mathrm{Ku}-$ denov and $P$. pacifica Takahashi. Polydora umangivora differs from $P$. woodwicki in lack of eyes, lack of notosetae on segment 5, major spines with distinct accessory tooth, and larger cup-shaped pygidium rather than four eyes, notosetae present on segment 5 , spines with accessory flange, and cuff-shaped pygidium.

Polydora umangivora differs from $P$. pacifica in rounded prostomium, caruncle length, number and morphology of major spines, and habitat. Polydora pacifica is a commensal of pearl oysters, Pinctada margaritifera (Linnaeus), from the Palau Islands. Polydora umangivora reaches maximal lengths of approximately $32 \mathrm{~mm}$ and 190 segments and has only four to seven exposed major spines; $P$. pacifica reaches lengths of $85 \mathrm{~mm}$ and 390 segments and has up to 17 major spines. Takahashi (1937:159-160, fig. 8) indicated that the hooded hooks of this species have a process below the main fang; his figure of the hooded hook shows a spur extending from the shaft of the hooded hook toward the main fang. Such a process has not been noted for any other polydorid species. Unfortunately, the presence of this structure could not be confirmed because attempts to locate type specimens were unsuccessful.

VARIABILITY: All specimens exhibited rounded prostomium and short caruncle extending to the middle of segment 1 through the end of segment $2(n=45)$. In some specimens the caruncle was in the form of a raised ridge or keel. Approximately 67\% of 

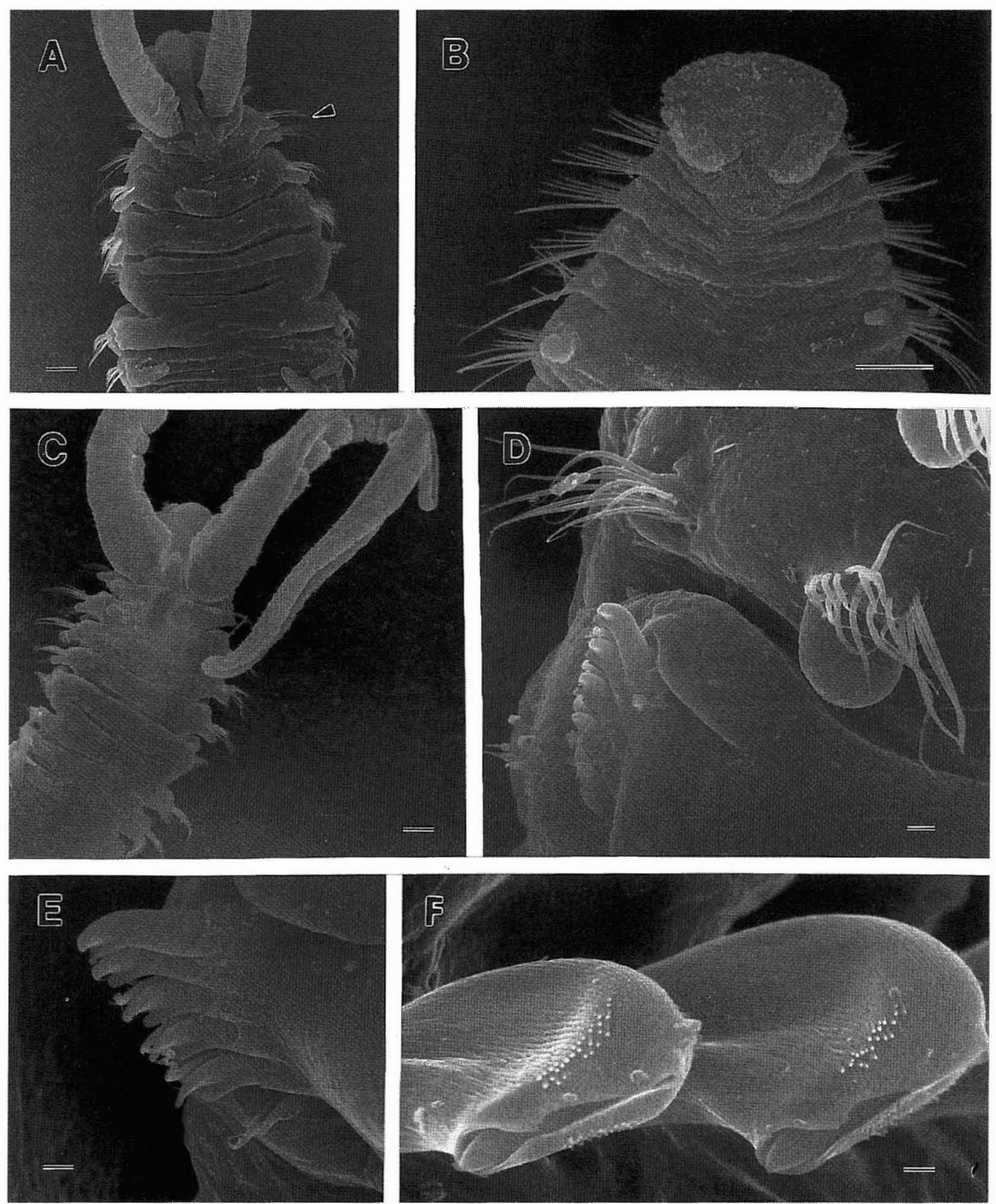

Figure 13. Polydora umangivora, n. sp.: paratypes (USNM 187571), SEM micrographs. $A$, Anterior end, dorsal view, arrowhead indicates segment 2 with two parapodia on right side; $B$, posterior end, dorsal view; $C$, anterior end, dorsal view; $D$, segments 4 and 5 with modified spines and accompanying setae; $E$, spines and companion setae of fifth segment, dorsal view; $F$, hooded hooks, apical view. Scale: $A-C, 100 \mu \mathrm{m} ; D, E, 10 \mu \mathrm{m} ; F, 1 \mu \mathrm{m}$. 
those specimens examined $(n=46)$ possessed distinct bright yellow/orange coloring that developed after preservation and covered the dorsal and ventral sides of anterior and posterior body segments. One specimen prepared for SEM was unique in possessing two parapodia on the right side of segment 2 (Figure 13A).

ECOLOGY: Polydora umangivora constructs U-shaped burrows within gastropod shells inhabited by hermit crabs. The species has been found to ingest the embryos attached to the pleopods of three host hermit crabs: $\mathrm{Cal}$ cinus gaimardii, Dardanus lagopodes, and $\mathrm{Pa}$ guristes runyanae. This report represents the second polydorid documented to prey on host hermit crab embryos. The feeding biology and ecology of the species will be treated in forthcoming papers (unpubl. data).

Distribution: Philippines: Bataan, Batangas, Oriental Mindoro, Palawan, Aklan, Cebu; Indonesia: Bali.

Polydora mabinii Williams, n. sp.

Figure 14

Holotype: Philippines: Batangas (USNM 187575), from Drupella cornus inhabited by Calcinus latens, Sombrero Island, 13 July 1997.

OTHER MATERIAL EXAMINED: Philippines: Batangas: 1 paratype (USNM 187573), from Latirus turritus inhabited by an unidentified hermit crab, Anilao, 28 June 1997; 1 paratype (USNm 187574), from Drupella cornus inhabited by Calcinus latens, Sombrero Island, 13 July 1997.

DESCRIPTION: Holotype broken, consisting of 33 anterior segments. Largest complete specimen measures $15.7 \mathrm{~mm}$ long, $0.3 \mathrm{~mm}$ wide at segment 7; 97 segments. Ovigerous female with ova in segments 20-58. Prostomium bifid; caruncle terminating on segments 3-4; occipital tentacle absent; two or four large eyes arranged in trapezoid (Figure $14 A$ ) or eyes absent. Palps extend posteriorly for 14-15 segments. In alcohol small spots of black pigmentation sparsely distributed along dorsal side and pygidium in some specimens; body opaque white.

Segment 1 with neurosetae, without notosetae, with well-developed notopodial lobes.
Winged capillary notosetae of segments 2-4, 6 , and subsequent segments in two rows; in segments 2-4 anterior and posterior rows subequal, with anterior row slightly shorter; on segment 6 anterior row geniculate and approximately half the length of the posterior row; reduced to three to five bilimbate notosetae in posterior segments; no specialized posterior notosetae. Winged capillary neurosetae of segments $2-4,6$, and subsequent segments in two rows, anterior row shorter then posterior; two to three bidentate hooded hooks begin on segment 7 , up to six in series at segment 14, not accompanied by capillaries; hooks with approximately right angle between main fang and shaft, wide angle between main fang and apical tooth, with slight constriction on shaft (Figure 14E).

Segment 5 slightly larger than preceding segments; row of two to four exposed major spines alternating with pennoned companion setae; with posterioventral fascicle of three to four winged neurosetae; anteriodorsal fascicle of two to four large geniculate notosetae with fine bristles (Figure 14D,F). Major spines simple, falcate (Figure 14D,F).

Branchiae begin on segments 8-9, continuing to middle portion of body; attaining full size at segment 11.

Pygidium cup-shaped with dorsal gap; covered with small papillae (Figure 14C).

ETYMology: The species is named after Mabini, a small port on Batangas Bay. The species is dedicated to the boatmen who work at the port and made travel to surrounding islands possible.

Remarks: Polydora mabinii belongs to the Polydora ciliata/websteri group and most closely resembles $P$. aggregata Blake and $P$. limicola. Polydora mabinii differs from $P$. aggregata by possessing simple, falcate major spines and anteriodorsal group of large geniculate setae, caruncle extending to segments $3-4$, and number of total segments (up to 97 segments and $16 \mathrm{~mm}$ long) instead of segment 5 with major spines with small elevation and anteriodorsal group of winged capillary notosetae, caruncle terminating bluntly on segment 2, and small number of segments (35-40 segments and 6-8 $\mathrm{mm}$ long) (Blake 1971). Polydora mabinii differs from $P$. limicola 


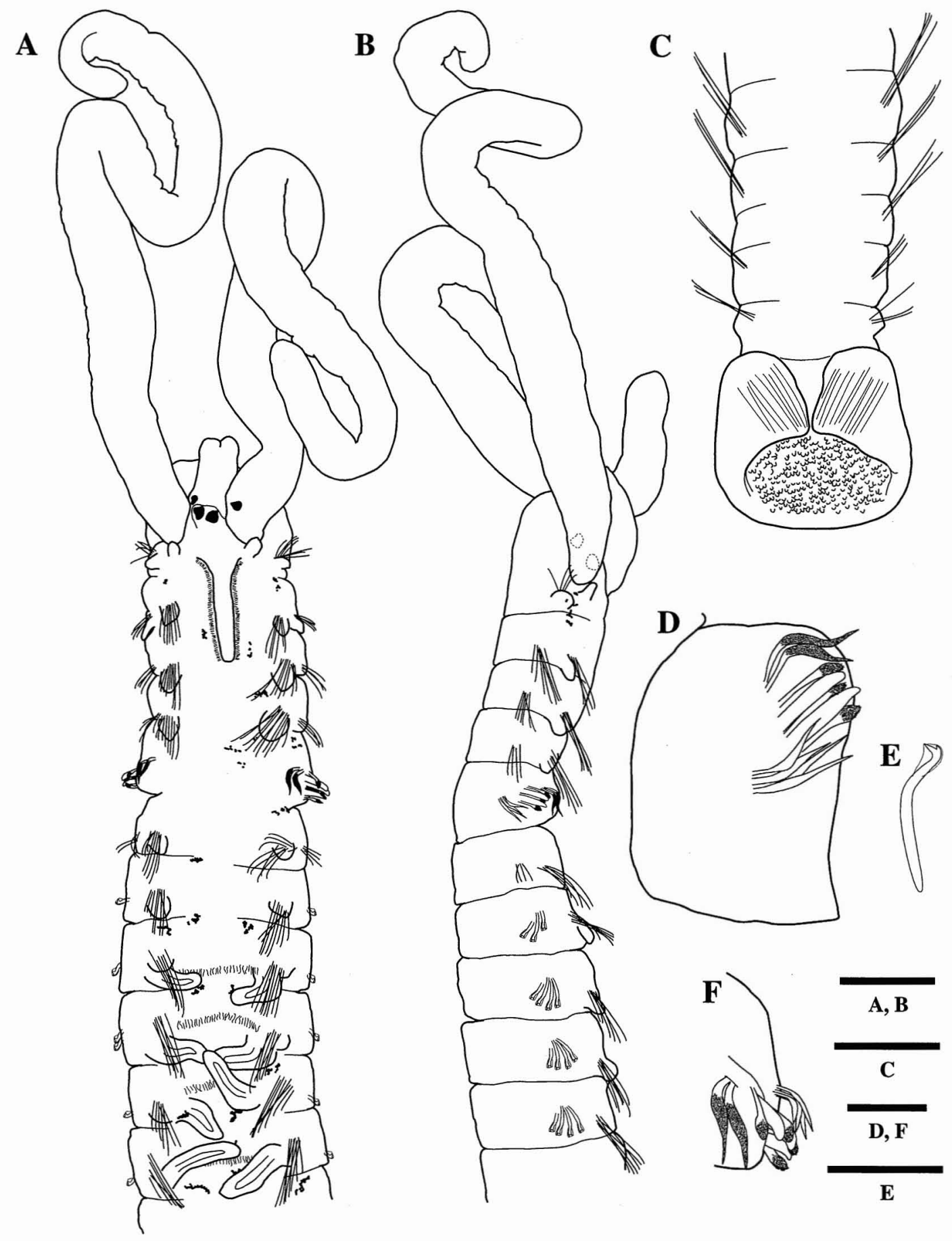

Figure 14. Polydora mabinii, n. sp.: holotype (USNM 187575) $(A, B, D-F)$ and paratype (USNM 187573) $(C)$. A, Anterior end, dorsal view; $B$, anterior end, lateral view; $C$, posterior end, dorsal view; $D$, fifth segment, lateral view of left side; $E$, bidentate hooded hook from anterior segment; $F$, fifth segment, dorsal view of right side. Scale: $A, B, C, 100 \mu \mathrm{m} ; D, E$, $F, 30 \mu \mathrm{m}$. 
in lack of palp pigmentation, segment 5 with simple, falcate major spines and anteriodorsal group of large geniculate setae instead of palps with black pigment bands, and segment 5 with major spines with small tooth and anteriodorsal group of winged capillary notosetae (Hartman 1961, Blake 1996). In addition, mature Polydora mabinii possess only four to five major spines in the fifth segment, but $P$. limicola contains 8-15 major spines. Difficulties in the taxonomy of P. limicola exist, and reports of this species may refer to more than one species (Williams and Radashevsky 1999).

ECOLOGY: Polydora mabinii has been found associated with gastropod shells (Drupella cornus and Latirus turritus) inhabited by hermit crabs (Calcinus latens). It is unknown if the species burrows into occupied shells or constructs tubes within the crevices of the shells. The presence of three gastropod veliger larvae within the gut of one of the specimens indicates that the species is a suspension feeder, capable of feeding on motile zooplankton.

Distribution: Philippines: Batangas.

Polydora robi Williams, 2000

Polydora robi Williams, 2000:539, figs. 1-4.

material examined: Philippines: Bataan: 12 spec. (UsNm 187576), from Cantharus undosus, Cypraea sp., Latirolagena smaragdula, and an unidentified gastropod shell inhabited by Calcinus gaimardii and Dardanus lagopodes, Mabayo, 21 February 1999; 5 spec. (USNM 187577), from Conus sp., Latirolagena smaragdula, and an unidentified gastropod shell inhabited by Calcinus gaimardii, Mabayo, 28 February 1999; 1 spec. (USNM 187578), from an unidentified gastropod shell inhabited by Diogenes sp., Morong, 6 February 1999; 3 spec. (usNm 187579), from Cantbarus undosus, Cypraea sp., and an unidentified gastropod shell inhabited by Calcinus gaimardii and Calcinus sp., Morong, 25 April 1999; Batangas: 9 spec. (USNm 187580), from Conus sp., Coralliophila neritoidea, Cypraea sp., Drupella cornus, D. rugosa, and Thais armigera (Link) inhabited by Calcinus gaimardii, C. latens, $C$. minutus, C. pulcher, Ciliopagurus strigatus, and Dardanus lagopodes, Anilao, 13 February 1999;
Oriental Mindoro: 12 spec. (USNM 187581), from Astralium rbodostoma, Conus sp., Cypraea sp., Drupa rubusidaeus, Drupella cornus, D. rugosa, Latirolagena smaragdula, Strombus labiatus labiatus, and an unidentified gastropod shell inhabited by Calcinus gaimardii, C. latens, and $C$. minutus, Puerto Galera: Coco Beach, 12 January 1999; 4 spec. (USNM 187582), from Drupella cornus inhabited by Calcinus gaimardii, C. latens, and C. minutus, Puerto Galera: Coco Beach, 14 January 1999; 2 spec. (UsNM 187583), from Drupella cornus and an unidentified gastropod shell inhabited by Calcinus gaimardii, Puerto Galera: Coco Beach, 15 January 1999; 3 spec. (USNm 187584), from Drupella cornus inhabited by Calcinus gaimardii, C. latens, and an unidentified hermit crab, Bayanan Beach, 13 January 1999; Aklan: 1 spec. (USNM 187585), from Strombus labiatus labiatus inhabited by Calcinus latens, Boracay: Rocky Beach, 12 April 1999; 3 spec. (UsNM 187586), from Cantharus undosus, Conus sp., and an unidentified gastropod shell inhabited by Calcinus gaimardii and C. latens, Boracay: Rocky Beach, 15 April 1999; Palawan: 2 spec. (USNM 187587), from Drupella rugosa inhabited by Paguristes runyanae, Magbautoc Island, 16 March 1999; 2 spec. (USNM 187588), from Tectus sp. and an unidentified gastropod shell inhabited by Calcinus gaimardii and Paguristes runyanae, Apulit Island, 17 March 1999; $1 \mathrm{spec}$. (USNM 187589), from Peristernia nassatula (Lamarck) uninhabited by hermit crab, Apulit Island, 18 March 1999.

DESCRIPTION: Up to $30.4 \mathrm{~mm}$ long, 1.1 mm wide at segment 7; 171 segments. Prostomium rounded; caruncle extending to middle of segment 2; short, triangular occipital tentacle at anterior margin of segment 1 ; eyes usually absent but two or four may be present in a row in juveniles. Palps extend posteriorly for 10-15 segments. In life, palps and body pale yellow, without pigmentation; in alcohol body opaque white.

Segment 1 with neurosetae, without notosetae. Winged capillary notosetae of segments $2-4,6$, and subsequent segments in two rows and a superior group of longer and thinner setae; notosetae in posterior one-third of body in flared or cone-shaped bundles of fine needlelike spines protruding through cuticle; approximately 85-95 spines in posterior 
segments with two to four longer anterior notosetae. Winged capillary neurosetae of segments 2-4, 6, and subsequent segments in two rows and an inferior tuft of capillaries. Bidentate hooded hooks begin on segment 7 , 15-27 hooks in middle body segments, not accompanied by capillaries; hooks with approximately right angle between main fang and apical tooth, with constriction on shaft, accompanying setae absent.

Segment 5 almost twice as large as segments 4 and 6 , with slightly curved row of four to eight exposed major spines alternating with pennoned companion setae; with posterioventral fascicle of four to nine winged neurosetae; notosetae absent. Major spines falcate, with lateral obliquely curved flange. Tear-shaped gland on each side of the fifth segment, ventral to the major spines with a duct leading to the sides of segment 5; gland in juveniles only.

Branchiae begin on segment 7 , continuing to terminal segments of body, small at first, attaining full size at segment 10 , diminishing in size in posterior segments. Dorsal ciliary bands begin on segment 7. Posterior segments with well-developed digitiform notopodia and enlarged neuropodia.

Pygidium small, with digitiform composite cirri surrounding anus; anal cirri longer on ventral side of pygidium, with irregular knoblike projections and nonmotile cilia.

remarks: Polydora robi was recently described by Williams (2000), who provided data on the variation, ecology, and feeding biology of the species. Previously the largest recorded specimen was $25.0 \mathrm{~mm}$ long for 117 segments. The original description was based on specimens collected from three provinces of the Philippines (Batangas, Cebu, and Mindoro) and Indonesia. Polydora robi has now been found in six provinces of the Philippines and is widely distributed in the country. Polydora robi ranges from 24 to 171 segments $(75 \pm 25, n=111)$ and $3-41 \mathrm{~mm}(16.4 \pm 9.5$, $n=40$ ) in size. Polydora robi was the first polydorid documented to feed on host hermit crab eggs. The ecology, feeding biology, reproduction, and larval development are treated in forthcoming papers (unpubl. data).

distribution: Philippines: Bataan, Batangas, Oriental Mindoro, Palawan, Aklan,
Cebu (Williams 2000; this paper); Indonesia: Bali (Williams 2000).

\section{Genus Tripolydora Woodwick, 1964}

Tripolydora Woodwick, 1964:155. Type species: Tripolydora spinosa Woodwick, 1964, by monotypy.

Diagnosis: Prostomium rounded, extending posteriorly as a broad caruncle to segment 3. Segment 1 without notosetae, notopodial lobes greatly reduced or absent. Segment 4 with anterior row of modified notosetae with inflated sheaths around a protruding shaft. Modified spines of segment 5 with terminal tooth and short knobs. Segments 7-10 with anterior row of unilimbate capillary notosetae containing riblike sheaths; posterior notosetae in bundles of long capillaries. Unilimbate capillary neurosetae replaced by tridentate hooded hooks on segment 9. Tridentate hooded hooks lack constriction on shaft, accompanied by capillary setae. Branchiae on segments 2-4, 6, and continuing to posterior segments. Pygidium composed of two ventral lappets and two smaller dorsal lappets.

\section{Tripolydora spinosa Woodwick, 1964}

Figure 15

Tripolydora spinosa Woodwick, 1964:155-157, fig. 4(6-9); Kohn and Lloyd, 1973b:700; Blake and Woodwick, 1981:352-362, figs. 1-5; Ward, 1987:368-369, fig. 3.II.I48.

Material examined: Philippines: Batangas: 1 spec. (USNM 187590), from Drupella cornus inhabited by Calcinus latens, Anilao, 13 February 1999. Chile: Easter Island: 1 spec. (USNM 49537), in tide pool, between Hanga Roa and Hanga Pika, 15 February 1969, leg. J. Randall.

DESCRIPTION: $6.6 \mathrm{~mm}$ long, $0.4 \mathrm{~mm}$ wide at segment $7 ; 39$ segments. Ovigerous female with ova in segments 12 to 26. Prostomium rounded; broad caruncle reaching end of segment 2; occipital tentacle and eyes absent (Figure 15A). Palps extend posteriorly for 15 segments. In life, black pigmentation bands on palps, prostomium, and dorsal side of an- 


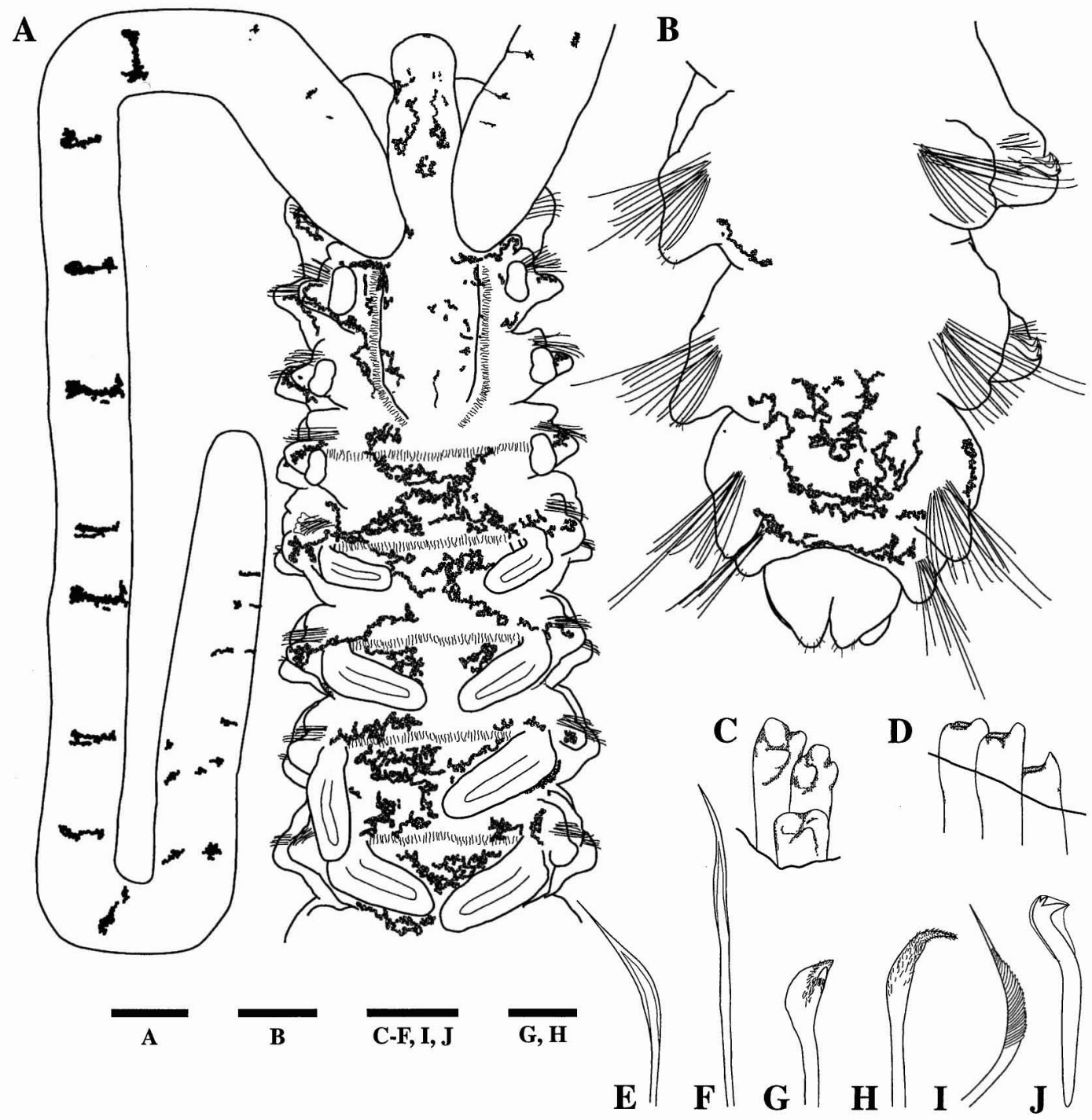

Figure 15. Tripolydora spinosa Woodwick (USNm 187590). $A$, Anterior end, dorsal view; $B$, posterior end, dorsal view; $C$, major spines of fifth segment, dorsal view; $D$, major spines of fifth segment, ventral view; $E$, fifth segment notosetae, anterior row; $F$, fifth segment notosetae, posterior row; $G$, modified setae of the fourth segment; $H$, notosetae of the fourth segment, middle row; $I$, unilimbate capillary notosetae of segment $7 ; \mathcal{F}$, tridentate hooded hook from anterior segment. Scale: $A, 100 \mu \mathrm{m} ; B, 50 \mu \mathrm{m} ; C-F, I, \mathcal{F}, 30 \mu \mathrm{m} ; G, H, 15 \mu \mathrm{m}$.

terior and posterior segments (Figure 15A). After preservation, black pigmentation bands absent on palps; color in alcohol opaque white.

Segment 1 with neurosetae; greatly reduced notopodia, without notosetae. Notose- tae of segments $2-10$ arranged in three rows; no specialized posterior notosetae. Notosetae of segments 2-3 and 6 are unilimbate capillaries. Segment 4 bears four notosetae with inflated sheaths containing bristles in anterior row; shaft of notosetae protruding from 
sheath (Figure $15 G$ ); middle row with short bilimbate notosetae with bristles, posterior row with long bilimbate notosetae (Figure $15 H$ ). Segments $7-10$ possess unilimbate capillary notosetae with riblike sheaths (Figure 15I); approximately eight unilimbate notosetae at segment 30 increasing to 24 at segment 36 and subsequent segments. Neurosetae of segments 2-8 with an anterior row of four to five pennoned setae and seven to eight longer unilimbate setae; four tridentate hooded hooks begin on segment 9 (Figure 157), initially accompanied by five to seven unilimbate capillaries, up to six hooded hooks in series at segment 11; unilimbate capillaries replaced by two to three simple capillaries and sabre setae on segment 27.

Segment 5 approximately same size as preceding segments, with three major spines and a ventral row of bilimbate neurosetae; two dorsal rows of bilimbate notosetae, posterior row longer than anterior row (Figure $15 E, F)$. Major spines with extended tooth and two short knobs; worn spines with reduced tooth (Figure 15C,D).

Branchiae begin on segment 2, continuing to segment 24; attaining full size at segment 7.

Pygidium composed of two ventral lappets and two dorsal lappets; lappets possessing nonmotile cilia (Figure 15B).

REMARKs: The single Philippine specimen agrees well with the published accounts of the species (Woodwick 1964, Blake and Woodwick 1981, Ward 1987). The pigmentation observed has not been previously noted, presumably because it disappears after preservation.

ECOLOGY: The specimen was in a mud tube within the gastropod shell Drupella cornus, inhabited by Calcinus latens. The species elsewhere is known to inhabit mud tubes constructed among coral rock, sand, algae, and sponges in addition to burrowing into dead coral (Woodwick 1964, Blake and Woodwick 1981, Ward 1987).

Distribution: Chile: Easter Island (Blake and Woodwick 1981); Hawai'i (Ward 1987); Marshall Islands: Eniwetok Atoll (Woodwick 1964); Philippines: Batangas (first record: this paper).
DISCUSSION

Table 1 summarizes data on the diversity of polydorids in seven of the best-studied areas of the Pacific. The central Pacific and IndoWest Pacific areas (Philippines, Hawai'i, and Marshall Islands) contain approximately equal numbers of polydorids (7-14 species among four to six genera), whereas North and Southwest Pacific areas contain approximately two to three times as many species (26-30 species among six to seven genera). The coral reef areas of the Indo-West Pacific harbor some of the most highly diverse faunal assemblages in the world. In particular, a small triangle (termed the East Indies Triangle) formed by the Philippines, the Malay Peninsula, and New Guinea is home to the greatest concentration of species within many tropical marine groups (Briggs 1999) including polychaetes (Knox 1957, Bailey-Brock 1995). The lower abundance of polydorids in the Indo-West Pacific is most likely due to lack of sampling rather than a true representation of the number of species in these areas. In fact, sampling efforts for spionids (in terms of numbers of researchers sampling as well as regions and habitats covered) in Japan and Australia have been considerably greater than in Indo-West Pacific areas such as the Philippines (see Blake and Kudenov 1978, Radashevsky 1993, Radashevsky and Hsieh 2000a,b). My study was restricted to polydorids associated with hermit crabs, a relatively small group of species that are predominately burrowers of calcareous substrata. When compared with the numbers of burrowers found in other areas, the diversity in the Philippines is closer to that in the North and Southwest Pacific (Table 1).

Of the 10 polydorid species recorded from the Philippines and Indonesia, four species (Dipolydora tridenticulata, Polydora umangivora, Polydora mabinii, and Polydora robi) are restricted to the Indo-West Pacific. Carazziella reishi is found throughout the Indo-West $\mathrm{Pa}$ cific, central Pacific islands, and Japan. Similarly, Tripolydora spinosa is found throughout the Indo-West Pacific, central Pacific islands, and Easter Island. Polydora cavitensis Pillai was previously recorded from among oysters in 
TABLE 1

Biodiversity of Nine Polydorid Genera within Seven Areas of the Pacific

\begin{tabular}{|c|c|c|c|c|c|c|c|}
\hline Genus & Hawai'i $^{a}$ & $\begin{array}{l}\text { Marshall } \\
\text { Islands }\end{array}$ & $\begin{array}{c}\text { New } \\
\text { Zealand }\end{array}$ & Australia & $\begin{array}{c}\text { Northwest } \\
\text { Pacific }\end{array}$ & Philippines & Taiwan \\
\hline \multicolumn{8}{|l|}{ Ampbipolydorab } \\
\hline Boccardia & 1 (1) & & $8 \quad(5)$ & $4 \quad(1)$ & 2 & 1 (1) & \\
\hline Boccardiella & 1 (1) & & 1 & $2 \quad(1)$ & (1) & & \\
\hline Carazziella & 1 (1) & $1 \quad(1)$ & & 4 & (1) & $1 \quad(1)$ & \\
\hline Dipolydora & 2 (2) & $2(2)$ & (3) & (6) & (9) & 3 (3) & \\
\hline Polydora & $5 \quad(2)$ & & (2) & (5) & (6) & $5 \quad(3)$ & $5 \quad(1)$ \\
\hline Polydorella & & & & 2 & & $2^{c}$ & \\
\hline Pseudopolydora & $3 \quad(1)$ & $3 \quad(2)$ & 1 & 3 & 2 & & 8 \\
\hline Tripolydora & 1 (1) & 1 (1) & & & & $1 \quad(1)$ & \\
\hline Total & 14 (9) & 7 (6) & $15 \quad(10)$ & $30 \quad(13)$ & $26 \quad(17)$ & 13 (9) & $13 \quad(1)$ \\
\hline
\end{tabular}

Note: Numbers indicate total species recorded within each genus; numbers in parentheses indicate species known to burrow in calcareous substrates. References: Hawai'i: Abbott 1946, Ward 1981, 1987, Bailey-Brock 1990, 2000; Marshall Islands: Woodwick 1964; New Zealand: Rainer 1973, Read 1975; Australia: Blake and Kudenov 1978, Hutchings and Turvey 1984; Northwest Pacific: Imajima and Hartman 1964, Radashevsky 1993, 1994a,b, Sato-Okoshi 1998, 1999; Philippines: Pillai 1965, Williams 2000; Taiwan: Radashevsky and Hsieh $2000 a, b$.

a Hawai'i contains two polydorids (Polydora nucbalis and Boccardia proboscidea) introduced via aquacultural products (Bailey-Brock 1990, 2000).

${ }^{b}$ Amphipolydora is a monotypic genus known only from Argentina (Blake 1983).

${ }^{c}$ Two Polydorella species have recently been found associated with sponges from the Philippines (unpubl. data).

the northern Philippines (Pillai 1965). The species has not been subsequently reported by any authors and was not encountered during this study; the species appears to be endemic to the Philippines. As currently defined, $D i$ polydora armata and $D$. socialis are widely distributed species in Atlantic and Pacific waters.

Previously, Boccardia berkeleyorum was known only from the eastern Pacific (California and Vancouver Island). This report represents the first record of the species in the Indo-West Pacific and represents a large range extension. Introductions of spionid polychaetes are well documented from numerous areas around the world via ballast water and aquacultural products (BaileyBrock 1990, 2000, Carlton and Geller 1993, Blake 1996, Röhner et al. 1996). For example, Polydora nuchalis Woodwick was presumably introduced to Hawai' $i$ through shipments of shrimp from Mexico. Similarly, Boccardia proboscidea was recently introduced to Hawai'i by shipments of Ostrea edulis Linnaeus from Maine (Bailey-Brock 1990, 2000). It is possible that Boccardia berkeleyorum was introduced to the Philippines through such human influence. The species is a burrower of calcareous substrates and could have impacts on mariculture in the Philippines.

\section{ACKNOWLEDGMENTS}

I thank Filipina B. Sotto for access to space at the Marine Laboratory of the University of San Carlos and Jason G. Young for his field assistance. I appreciate the help of Paul Cassidy (Western Washington University) and Alan W. Harvey (Georgia Southern University) in identification of hermit crabs, John Clamp (North Carolina Central University) in identification of ciliates, and Christopher B. Boyko (University of Rhode Island and the American Museum of Natural History) in identification of gastropod species. Linda Ward (National Museum of Natural History) kindly tracked down older literature references. I thank my committee members, Robert Bullock, Emily Carrington, Barbara Sullivan, and James Blake, for their reviews of early versions of the manuscript.

\section{Literature Cited}

Abbott, D. P., Jr. 1946. Some polychaetous annelids from a Hawaiian fish pond. Univ. Hawaii Res. Publ. 23:5-24.

Bailey-Brock, J. H. 1990. Polydora nuchalis (Polychaeta: Spionidae), a new Hawaiian record from aquaculture ponds. Pac. Sci. 44:81-87. 
1995. Polychaetes of western Pacific Islands: A review of their systematics and ecology. Pages 1-424 in M. N. A. Peterson, J. E. Maragos, L. G. Eldredge, J. E. Bardach, and H. F. Takeuchi, eds. Marine and coastal biodiversity in the tropical island Pacific Region. East-West Center, Honolulu.

. 2000. A new record of the polychaete Boccardia proboscidea (Family Spionidae), imported to Hawai'i with oysters. Pac. Sci. 54:27-30.

Berkeley, E. 1927. Polychaetous annelids from the Nanaimo District. 3. Leodicidae to Spionidae. Contrib. Can. Biol. Fish., n. s., 3:405-422.

Berkeley, E., and C. Berkeley. 1936. Notes on Polychaeta from the coast of western Canada. 1. Spionidae. Ann. Mag. Nat. Hist., ser. 10, 18:468-476.

- 1952. Annelida. Polychaeta Sedentaria. Can. Pac. Fauna 9b. Fisheries Research Board of Canada Part 2:1-139.

Blake, J. A. 1971. Revision of the genus Polydora from the east coast of North America (Polychaeta: Spionidae). Smithson. Contrib. Zool. 75:1-32.

. 1975. Phylum Annelida: Class Polychaeta. Pages 151-243 in R. I. Smith and J. T. Carlton, eds. Light's Manual, Intertidal invertebrates of the central California coast. University of California Press, Berkeley. . 1979a. Four new species of Carazziella (Polychaeta: Spionidae) from North and South America, with a redescription of two previously described forms. Proc. Biol. Soc. Wash. 92:466-481.

1979b. Revision of some polydorids

(Polychaeta: Spionidae) described and recorded from British Columbia by Edith and Cyril Berkeley. Proc. Biol. Soc. Wash. 92:606-617.

. 1981. Polydora and Boccardia species (Polychaeta: Spionidae) from western Mexico, chiefly from calcareous habitats. Proc. Biol. Soc. Wash. 93:947-962.

- 1983. Polychaetes of the family Spionidae from South America, Antarctica and adjacent seas and islands. Antarct. Res. Ser. 39:205-288.

- 1986. A new species of Boccardia
(Polychaeta: Spionidae) from the Galápagos Islands and redescription of $\mathrm{Boc}$ cardia basilaria Hartman from southern California. Bull. South. Calif. Acad. Sci. 85:16-21.

1996. Family Spionidae Grube, 1850. Including a review of the genera and species from California and a revision of the genus Polydora Bosc, 1802. Pages 81-223 in J. A. Blake, B. Hilbig, and P. H. Scott, eds. Taxonomic atlas of the benthic fauna of the Santa Maria Basin and western Santa Barbara Channel. Vol. 6. Santa Barbara Museum of Natural History, Santa Barbara, California.

Blake, J. A., and P. L. Arnofsky. 1999. Reproduction and larval development of the spioniform Polychaeta with application to systematics and phylogeny. Hydrobiologia 402:57-106.

Blake, J. A., and J. W. Evans. 1973. Polydora and related genera as borers in mollusk shells and other calcareous substrates. Veliger 15:235-249.

Blake, J. A., and J. D. Kudenov. 1978. The Spionidae (Polychaeta) from southeastern Australia and adjacent areas with a revision of the genera. Mem. Natl. Mus. Vic. 39:171-280.

. 1981. Larval development, larval nutrition, and growth for two Boccardia species (Polychaeta: Spionidae) from Victoria, Australia. Mar. Ecol. Prog. Ser. 6:175182.

Blake, J. A., and N. J. Maciolek. 1987. A redescription of Polydora cornuta Bosc (Polychaeta: Spionidae) and designation of a neotype. Proc. Biol. Soc. Wash. 7:11-15.

Blake, J. A., and K. H. Woodwick. 1971. A review of the genus Boccardia Carazzi (Polychaeta: Spionidae) with descriptions of two new species. Bull. South. Calif. Acad. Sci. 70:31-42.

1981. The morphology of Tripolydora spinosa Woodwick (Polychaeta: Spionidae): An application of the scanning electron microscope to polychaete systematics. Proc. Biol. Soc. Wash. 94:352-362.

Bosc, L. A. G. 1802. Histoire naturelle des vers, contenant leur déscription et leurs moeurs, avec figures dessinées d'après nature. Vols. 1-3: 1-324. Deterville, Paris. 
Briggs, J. C. 1999. Coincident biogeographic patterns: Indo-West Pacific Ocean. Evolution 53:326-335.

Buckley, W. J., and J. P. Ebersole. 1994. Symbiotic organisms increase the vulnerability of a hermit crab to predation. J. Exp. Mar. Biol. Ecol. 182:49-64.

Buzhinskaja, G. N. 1985. Polychaeta of the shelf off South Sakhalin and their ecology. Issled. Fauny Morei SSSR 30:72-224.

Caceres-Martinez, J., G. D. Tinoco, M. L. U. Bustamante, and I. M. Gomez-Humaran. 1999. Relationship between the burrowing worm Polydora sp. and the black clam Cbione fuctifraga Sowerby. J. Shellfish Res. 18:85-89.

Carazzi, D. 1893. Revisione del genero Polydora Bosc, e cenni su due specie che vivono sulle ostriche. Mitt. Zool. Stat. Neapel 11:4-45.

Carlton, J. T., and J. B. Geller. 1993. Ecological roulette: The global transport of nonindigenous marine organisms. Science (Washington, D.C.) 261:78-82.

Carrasco, F. D. 1974. Spionidae (Polychaeta) provenientes de la Bahía de Concepción y lugares adyacentes. Bol. Soc. Biol. Concepcion 48:185-201.

Czerniavsky, V. 1881. Materialia ad zoographiam Ponticam comparatum. 3 Vermes. Bull. Soc. Imp. Nat. Moscou 56:338-420.

Day, J. H. 1954. The Polychaeta of Tristan da Cunha. Results of the Norwegian Scientific Expedition to Tristan da Cunha 1937-1938. Nor. Vidensk. Akad. Oslo Arbok. 29:1-35.

- 1967. A monograph on the Polychaeta of southern Africa. Br. Mus. (Nat. Hist.) Publ. 656:1-878.

Ehlers, E. 1905. Neuseelandische Anneliden. Abh. Königlichen Ges. Wiss. Göttingen, Mathematisch-Physikalische Klasse 3:180.

Fauvel, P. 1927. Polychètes sédentaires. Addenda aux Errantes, Archiannélides, Myzostomaires. Faune de France 16:1-494.

Foster, N. M. 1971. Spionidae (Polychaeta) of the Gulf of Mexico and the Caribbean Sea. Stud. Fauna Curacao Other Caribb. Isl. 36:1-183.

Guérin, J. P. 1990. Description d'une nou- velle espece de spionide (annelides, polychetes) Boccardia semibranchiata. Ann. Inst. Oceanogr. 66:37-45.

Hartman, O. 1941. Some contributions to the biology and life history of Spionidae from California. Allan Hancock Found. Pac. Exped. 7:289-323.

. 1954. Marine annelids from the northern Marshall Islands. Prof. Pap. U.S. Geol. Surv. (no. 260): 615-644.

. 1961. Polychaetous annelids from California. Allan Hancock Pac. Exped. 25:1-226.

1969. Atlas of the sedentariate polychaetous annelids from California. Allan Hancock Foundation, University of Southern California, Los Angeles.

Hartmann-Schröder, G. 1962. Die Polychaeten des Eulitorals. Pages 57-167 in G. Hartmann-Schröder and G. Hartmann, eds. Zur Kenntnis des Eulitorals der chilenischen Pazifikküste und argentinischen Küste. Mitt. Hamb. Zool. Mus. Inst. 60 .

1965. Die Polychaeten des Sublitorals. Pages 59-305 in G. HartmannSchröder and G. Hartmann, eds. Zur Kenntnis des Sublitorals der chilenischen Küste under besonderer Berücksichtigung der Polychaeten und Ostracoden. Mitt. Hamb. Zool. Mus. Inst. 60.

. 1979. Die Polychaeten der tropischen Nordwestküste Australiens (zwischen Derby im Norden und Port Hedland im Süden). Pages 75-218 in G. Hartmann-Schröder and G. Hartmann, eds. Zur Kenntnis der Eulitorals der australischen Küsten unter besonderer Berücksichtigung der Polychaeten und Ostracoden (Teil 2 und Teil 3). Mitt. Hamb. Zool. Mus. Inst. 76.

Haswell, W. F. 1885. On a destructive parasite of the rock oyster. Proc. Linn. Soc. N.S.W. 10:273-275.

Hoberg, M. K., S. G. McGee, and H. M. Feder. 1982. Polychaetes and amphipods as commensals with pagurids from the Alaska shelf. Ophelia 21:167-179.

Hutchings, P. A., and S. P. Turvey. 1984. The Spionidae of South Australia (Annelida: Polychaeta). Trans. R. Soc. S. Aust. 108:1-20. 
(ICZN) International Commission on Zoological Nomenclature. 1999. International Code of Zoological Nomenclature, 4th ed. ICZN, London.

Imajima, M., and O. Hartman. 1964. The polychaetous annelids of Japan. Part II. Allan Hancock Found. Occas. Pap. 26: $239-452$.

Jensen, K., and K. Bender. 1973. Invertebrates associated with snail shells inhabited by Pagurus bernbardus (L.) (Decapoda). Ophelia 10:185-192.

Johnson, P. G. 1984. Family Spionidae Grube, 1850. Pages 6-1 to 6-99 in J. M. Uebelacker and P. G. Johnson, eds. Taxonomic guide to the polychaetes of the northern Gulf of Mexico. Barry A. Vittor and Associates, Inc., Mobile.

Johnston, G. 1838. Miscellanea Zoologica. Aricidae. Mag. Zool. Bot. 2:63-72.

Jones, M. L. 1962. On some polychaetous annelids from Jamaica. Bull. Am. Mus. Nat. Hist. 124:173-212.

Karlson, R. H., and M. A. Shenk. 1983. Epifaunal abundance, association, and overgrowth patterns on large hermit crab shells. J. Exp. Mar. Biol. Ecol. 70:55-64.

Khlebovitsch, V. V. 1959. [Some species of polychaete worms from the Kurile Islands, which are new or recorded for the first time in the U.S.S.R.] Zool. Zh. 28:167181.

Kinberg, J. 1866. Annulata nova. Öfversight af Kungliga Vetenskaps-Akademiens Förhandlingar, Stockholm 22:239-258.

- 1910. Kongliga Svenska Fregatten Eugenies Resa omkring jorden under befäl af C.A. Virgin åren 1851-1853. Zoologi. 3. Annulater., pp. 1-78.

Knox, G. A. 1957. The distribution of polychaetes within the Indo-Pacific. Proc. 8th Pac. Sci. Congr. 3:403-411.

Kohn, A. J., and M. C. Lloyd. 1973a. Polychaetes of truncated reef limestone substrata on eastern Indian Ocean coral reefs: Diversity, abundance, and taxonomy. Int. Rev. Gesamten Hydrobiol. 58:369-399.

- 1973b. Marine polychaete annelids of Easter Island. Int. Rev. Gesamten Hydrobiol. 58:691-712.

Kojima, H., and M. Imajima. 1982. Burrowing polychaetes in the shells of abalone
Haliotis diversicolor aquatilis chiefly on species Polydora. Bull. Jpn. Soc. Sci. Fish. 48:31-35.

Langerhans, P. 1880. Die Wurmfauna von Madeira. Z. Wiss. Zool. 34:87-143.

Lewis, J. B. 1998. Reproduction, larval development and functional relationships of the burrowing, spionid polychaete Dipolydora armata with the calcareous hydrozoan Millepora complanata. Mar. Biol. (Berl.) 130:651-662.

Light, W. J. 1977. Spionidae (Annelida: Polychaeta) from San Francisco Bay, California: A revised list of nomenclatural changes, new records, and comments on related species from the northeastern Pacific. Proc. Biol. Soc. Wash. 90:66-88. 1978. Invertebrates of the San Francisco Bay estuary system. Family Spionidae (Annelida, Polychaeta). The Boxwood Press, Pacific Grove, California.

Lissner, A., C. Phillips, D. Cadien, R. Smith, B. Bernstein, R. Cimberg, T. Kauwling, and W. Anikouchine. 1986. Assessment of long-term changes in biological communities in the Santa Maria Basin and western Santa Barbara Channel. Phase I. Final report submitted for the Minerals Management Service: U.S. Department of the Interior, Pacific OCS Office. Contract No. 14-12-0001-30032. NMS OCS Study, MMS 86-0012.

Martin, D. 1996. A new species of Polydora (Polychaeta, Spionidae) associated with the excavating sponge Cliona viridis (Porifera, Hadromerida) in the northeastern Mediterranean Sea. Ophelia 45:159-174.

Martin, D., and T. A. Britayev. 1998. Symbiotic polychaetes: Review of known species. Oceanogr. Mar. Biol. Annu. Rev. 36:217340.

Möbius, K. 1874. Mollusken, Würmer, Echinodermen und Coelenteraten. Die zweite deutsche Nordpolarfahrt in den Jahren 1869 und 1870 unter Führung des Käpitans Karl Koldewey. Herausgegeben von den Verein fuer di deutsche Norpolarfahrtin Bremen. Wiss. Ergeb. 2:246261.

Oersted, A. S. 1843. Annulatorum danicorum conspectus. Naturhistorisk I Maricolae. Tidsskrift København 4:1-51. 
Okuda, S. 1937. Spioniform polychaetes from Japan. J. Fac. Sci. Hokkaido Univ. 5:217254.

Paxton, H., and L. M. Chou. 2000. Polychaetous annelids from the South China Sea. Raffles Bull. Zool. Suppl. 8:209-232.

Pettibone, M. H. 1967. Type-specimens of polychaetes described by Edith and Cyril Berkeley (1923-1964). Proc. U.S. Natl. Mus. 119:1-23.

Pillai, T. G. 1965. Annelida Polychaeta from the Philippines and Indonesia. Ceylon J. Sci. Biol. Sci. 5:110-177.

Radashevsky, V. I. 1993. Revision of the genus Polydora and related genera from the North West Pacific (Polychaeta: Spionidae). Publ. Seto Mar. Biol. Lab. 36:1-60.

. 1994a. Species of the genus Polydora (Polychaeta, Spionidae) from the middle Kurile Islands. Bull. Natl. Sci. Mus. Ser. A (Zool.) 20:67-76.

. 1994b. Life history of a new Polydora species from the Kurile Islands and evolution of lecithotrophy in polydorid genera (Polychaeta: Spionidae). Ophelia 39:121136.

Radashevsky, V. I., and H. L. Hsieh. 2000a. Polydora (Polychaeta: Spionidae) species from Taiwan. Zool. Stud. 39:203-217.

- 2000b. Pseudopolydora (Polychaeta: Spionidae) species from Taiwan. Zool. Stud. 39:218-235.

Radashevsky, V. I., and J. D. Williams. 1998. Polydora websteri Hartman in Loosanoff \& Engle, 1943 (Annelida, Polychaeta): Proposed conservation of the specific name by a ruling that it is not to be treated as a replacement name for $P$. caeca Webster, 1879 , and designation of a lectotype for P. websteri. Bull. Zool. Nomencl. 55:212216.

Rainer, S. 1973. Polydora and related genera (Polychaeta: Spionidae) from Otago waters. J. R. Soc. N.Z. 3:545-564.

Read, E. 1975. Systematics and ecology of polydorid species (Polychaeta: Spionidae) from Wellington Harbour. J. R. Soc. N.Z. 5:395-419.

Reish, D. J. 1968. A biological survey of the Bahia de Los Angeles, Gulf of California, Mexico. II. Benthic polychaetous annelids.
Trans. San Diego Soc. Nat. Hist. 15:67106.

Rice, S. A. 1978. Spermatophores and sperm transfer in spionid polychaetes. Trans. Am. Microsc. Soc. 97:160-170.

Röhner, M., Bastrop, R., and K. Jürss. 1996. Colonization of Europe by two American genetic types or species of the genus Marenzelleria (Polychaeta: Spionidae). An electrophoretic analysis of allozymes. Mar. Biol. (Berl.) 127:277-287.

Sato-Okoshi, W. 1998. Three new species of polydorids (Polychaeta, Spionidae) from Japan. Species Diversity 3:277-288.

1999. Polydorid species (Polychaeta, Spionidae) in Japan, with descriptions of morphology, ecology and burrow structure. 1. Boring species. J. Mar. Biol. Assoc. U.K. 79:831-848.

Sato-Okoshi, W., and K. Okoshi. 1997. Survey of the genera Polydora, Boccardiella and Boccardia (Polychaeta, Spionidae). Bull. Mar. Sci. 60:482-493.

Schmarda, L. K. 1861. Neue wirbellose Thiere beobachtet und gesammelt auf einer Reise um die Erde 1853 bis 1857. Vol. 1. Turbellarien, Rotatorien und Anneliden. Pt. 2:1-164.

Stachowitsch, M. 1980. The epibenthic and endolithic species associated with the gastropod shells inhabited by the hermit crabs Paguristes oculatus and Pagurus cuanensis. Mar. Ecol. 1:73-101.

Steinhauer, M., and E. Imamura. 1990. California OCS Phase II Monitoring Program three year annual report. Vol. I. Submitted to the U.S. Department of the Interior, Minerals Management Service, Pacific OCS Region, under Contract No. 14-120001-30262.

Takahashi, K. 1937. Notes on the polychaetous annelid, Polydora pacifica n. sp., which bores holes in Pinctada margaritifera (Linné). Stud. Palao Trop. Biol. Stn. 2:155-167.

Verrill, A. E. 1879. Notice of recent additions to the marine invertebrata, of the northeastern coast of America, with descriptions of new genera and species and critical remarks on others. Part 1, Annelida, Gephyrea, Nemertina, Nematoda, Polyzoa, 
Tunicata, Mollusca, Anthozoa, Echinodermata, Porifera. Proc. U.S. Natl. Mus. 2:165-205.

1881. New England Annelida. Part 1.

Historical sketch, with annotated list of species hitherto recorded. Trans. Conn. Acad. Arts Sci. 4:285-324.

Walker, S. E. 1995. Taphonomy of modern and fossil intertidal gastropod associations from Isla Santa Cruz and Isla Santa Fe, Galápagos Islands. Lethaia 28:371-382.

Ward, L. A. 1981. Spionidae (Polychaeta: Annelida) from Hawaii, with descriptions of five new species. Proc. Biol. Soc. Wash. 94:713-730.

1987. Family Spionidae. Pages 340 369 in D. M. Devaney and L. G. Eldredge, eds. Reef and shore fauna of Hawaii, 64. Bishop Museum Press, Honolulu.

Webster, H. E. 1879. Annelida Chaetopoda of the Virginia coast. Trans. Albany Inst. N.Y. 9:202-269.

Williams, J. D. 2000. A new species of Polydora (Polychaeta: Spionidae) from the
Indo-West Pacific and first record of host hermit crab egg predation by a commensal polydorid worm. Zool. J. Linn. Soc. 129:537-548.

. 2001. Reproduction and larval development of Polydora robi (Polychaeta: Spionidae), an obligate commensal of hermit crabs from the Philippines. Invertebr. Biol. 120:237-247.

Williams, J. D., and J. J. McDermott. 1997. Feeding behavior of Dipolydora commensalis (Polychaeta: Spionidae): Particle capture, transport, and selection. Invertebr. Biol. 116:115-123.

Williams, J. D., and V. I. Radashevsky. 1999. Morphology, ecology, and reproduction of a new Polydora species (Polychaeta: Spionidae) from the east coast of North America. Ophelia 51:115-127.

Woodwick, K. H. 1964. Polydora and related genera (Annelida, Polychaeta) from Eniwetok, Majuro, and Bikini Atolls, Marshall Islands. Pac. Sci. 18:146-159. 